\title{
Species of the genus Fusarium and Fusarium toxins in the grain of winter and spring wheat in Poland
}

\author{
Gatunki z rodzaju Fusarium oraz toksyny fuzaryjne w ziarnie pszenicy ozimej i jarej \\ w Polsce
}

\section{Tomasz Góral ${ }^{1 \oplus 凶}$, Piotr Ochodzki ${ }^{1 \oplus}$, Linda Kærgaard Nielsen², Dorota Walentyn-Góral ${ }^{1}$}

\author{
${ }^{1}$ Plant Breeding and Acclimatization Institute - National Research Institute, Radzików, Poland \\ 2 Sejet Plant Breeding, Horsens, Denmark \\ $\bowtie$ e-mail: t.goral@ihar.edu.pl
}

\begin{abstract}
The aim of the study was to determine the presence of Fusarium species and mycotoxins in wheat grain from harvest in 2009 and 2010 in Poland. Samples from different locations were analyzed for the content of DNA of Fusarium species and mycotoxins. In 2009, DNA of $F$. graminearum and $F$. poae was present in all samples, $F$. culmorum in $82 \%$ of samples, and $F$. avenaceum in 55\% of samples. In 2010, the highest content of DNA was found for F. graminearum followed by $F$. avenaceum, $F$. poae and $F$. langsethiae. The amount of $F$. culmorum DNA was very low. The most frequently occurring species were $F$. poae and F. graminearum, however, the amount of $F$. poae DNA was lower. In 2009, deoxynivalenol was detected in all samples. In 2010, the average content of deoxynivalenol was lower than in 2009. Nivalenol was detected at very low concentration in both years. Significant correlations between content of $F$. graminearum DNA and deoxynivalenol concentration in the grain and between content of $F$. poae DNA and nivalenol concentration in the grain in 2009 were found.
\end{abstract}

\begin{abstract}
Keywords: deoxynivalenol, DNA, Fusarium head blight, nivalenol, real-time PCR, trichothecenes, zearalenone
Celem badania było określenie obecności gatunków Fusarium i mykotoksyn występujących w ziarnie pszenicy w Polsce w latach 2009 i 2010. Próby ziarna pochodzące z różnych regionów Polski zostały przeanalizowane pod kątem zawartości DNA grzybów z rodzaju Fusarium oraz mykotoksyn. W 2009 roku DNA F. graminearum i F. poae było obecne we wszystkich próbach, F. culmorum w 82\% prób, $F$. avenaceum w 55\% próbek. W 2010 r. najwyższą zawartość DNA stwierdzono dla $F$. graminearum, a następnie $F$. avenaceum, $F$. poae i $F$. langsethiae. Ilość DNA F. culmorum była bardzo niska. Najczęściej występującymi gatunkami były $F$. poae i $F$. graminearum. Jednakże ilość DNA F. poae była niższa. W 2009 r. we wszystkich próbach wykryto deoksyniwalenol. W 2010 r. średnia zawartość deoksyniwalenolu była niższa niż w 2009 r. Niwalenol wykryto w bardzo niskim stężeniu w obu latach. Stwierdzono istotność korelacji między zawartością DNA F. graminearum a stężeniem deoksyniwalenolu w ziarnie oraz między zawartością DNA F. poae a stężeniem niwalenolu w ziarnie w 2009 r.
\end{abstract}

Słowa kluczowe: deoksyniwalenol, DNA, fuzarioza kłosów, niwalenol, real-time PCR, trichoteceny, zearalenon

\section{Introduction}

Fusarium head blight (FHB) is a disease of wheat caused by a complex of toxicogenic fungi of the genus Fusarium (Parry et al. 1995). The main species of this complex in Europe are $F$. graminearum and $F$. culmorum identified as deoxynivalenol (DON), nivalenol (NIV) and zearalenone (ZEN) producers. However, other Fusarium species producing mycotoxins are also prevalent: $F$. avenaceum - moniliformin, enniatins and beauvericin (BEA) producer; $F$. poae - NIV, BEA producer. Fusarium langsethiae and F. sporotrichioides - T-2 and HT-2 toxins producers are also prevalent (Bottalico and Perrone 2002; Jestoi et al. 2008; Vogelgsang et al. 2008; Somma et al. 2010; Imathiu et al. 2013). Fusarium graminearum and F. culmorum are highly pathogenic species, which can cause severe epidemics of FHB. The other species are medium or weakly pathogenic, however, due to the wide prevalence, they may also cause mycotoxin contamination of grain (Uhlig et al. 2007; Yli-Mattila et al. 2008; Nielsen et al. 2011; Dinolfio and Stenglein 2014).

Because of the diversity of Fusarium species causing FHB, monitoring of changes in the Fusarium population on wheat is important. Frequency of species infecting wheat 
is not stable and changes depending on the weather in particular year (Xue et al. 2019). Differences are also observed between regions of wheat production in Europe. For example, other species dominate in North-Eastern Europe (equal share of three species $F$. avenaceum, $F$. culmorum, $F$. graminearum) than in south-western part of the continent (mainly F. graminearum) (Bottalico and Perrone 2002). Species compositions changes over time, which is the results of climate warming, and changes in the acreage of major cereal crops -particularly increase of the maize area (Sundheim et al. 2013; Hofgaard et al. 2016; Maiorano et al. 2008; Vaughan et al. 2016). The main reported effect of the above factors is increase in F. graminearum occurrence and decrease in F. culmorum (Parikka et al. 2012; Miller 2008; Scherm et al. 2013; Hofgaard et al. 2016; Bilska et al. 2018). Chandelier et al. (2011) analysed winter wheat samples from Belgium over 2003-2009 period. They found that main species were $F$. avenaceum and $F$. graminearum; however, their frequency changed depending on year from 20 to $100 \%$. The frequency of $F$. poae was relatively constant over the years (about $70 \%$ ). The overall incidence of $F$. culmorum decreased during the study, from $80 \%$ in 2003 to $10 \%$ over the final three years. Similarly, Isebaert et al. (2009) observed that $F$. graminearum and F. culmorum were the most important species in Northern Belgium in 2002-2005. They found correlation between crop prevalence and both species frequency. F. graminearum dominated in areas of maize cultivation, F. culmorum in areas small grain cereals cultivation. In Luxemburg, the most common species isolated from wheat heads were $F$. graminearum, $F$. avenaceum and $F$. poae. Increase of frequency of $F$. graminearum and decrease in F. culmorum were observed (Giraud et al. 2010). Winter wheat cultivated in the Netherlands in 2009 was studied for Fusarium species and toxins (van der Fels-Klerx et al. 2012). In samples collected on harvest, authors found dominance of $F$. graminearum. F. avenaceum and Microdochium nivale were also frequent. However, in the pre-harvest samples, only $F$. graminearum and $M$. nivale were present. Waalwijk et al. (2004) analysed wheat heads and grain collected in the Netherlands in 2001 and 2002. In 2001, in samples collected at late milk stage, F. graminearum was predominant; however, some samples contained also $F$. avenaceum and/or F. culmorum. At harvest, $F$. graminearum dominated almost completely. In 2002 the weather conditions were more favorable for FHB, and they found relative dominance of $F$. graminearum in grain from the Netherlands and almost complete in samples from France. According to Birzele et al. (2002) in 1997 and 1998 the dominating species in Germany in wheat grain were $F$. avenaceum, F. poae, F. culmorum and $F$. graminear$u m$. Frequencies of two last species were similar, however percentage of $F$. graminearum increased in 1998. In Germany in 2008, F. graminearum sensu stricto was the predominant species followed by F. culmorum. Other species (F. poae, F. tricinctum, $M$. nivale etc.) were identified in small amounts (Talas et al. 2011). Similar results were obtained by Birr et al. (2020) who analyzed winter wheat grain samples from seven locations in Germany from 2013 to 2017. In Hungary, in year 2010, which was very favorable for FHB development, predominantly $F$. graminearum was isolated from wheat grain (Laszlo et al. 2011).

Waalwijk et al. (2003) analyzed wheat ears with FHB symptoms collected in Netherlands in 2000 and 2001. They found that $F$. graminearum was the dominating Fusarium species in both years. As they stated, this was significant change comparing results from the 1980s and 1990s, which showed that $F$. culmorum was_the predominant species in the Netherlands. They presume that this shift could be connected with an increase in maize acreage. F. graminearum, unlike $F$. culmorum, is a major pathogen on maize and, can survive on maize debris (Xu and Nicholson 2009; Maiorano et al. 2008). The other factor could be climate warming which favors $F$. graminearum as it has higher optimal temperature of development (Vaughan et al. 2016)._The good example of this shift can be first detection of $F$. graminearum in wheat grain collected in 2017 in West Siberia, Russia (Gagkaeva et al. 2019) as well as absence of $F$. graminearum until 2012 in FHB infected cereal (Suproniené et al. 2010, 2016)

The prevalence of FHB pathogens differed significantly between studied countries in 2001 and 2002 (UK, Ireland, Italy and Hungary) (Xu et al. 2005). Overall, all pathogens (F. graminearum, F. culmorum, F. avenaceum and $F$. poae) were commonly detected in Ireland and to a lesser extent in the UK. In contrast, only two species, $F$. graminearum and $F$. poae, were regularly detected in Italy and Hungary. Fusarium culmorum was rarely detected except in Ireland. The latter country has the coolest summer weather among four studied countries. Authors stated that the increase in $F$. graminearum, especially in the UK, appears to have been at the expense of F. culmorum. The replacement of F. culmorum 
by $F$. graminearum as the predominant FHB pathogen was also reported in Bavaria (Obst et al. 1997) where the change was linked with increased maize production in Poland in years 2016 and 2017 more than $80 \%$ of isolates collected from symptomatic wheat heads were $F$. graminearum, and less than $4 \%$ were $F$. culmorum (Bilska et al. 2018). $F$. graminearum dominated in wheat grain in 2012, and was replaced by F. poae in 2013 (Wolny-Koładka et al. 2015). It is worth to notice that in Poland grain maize acreage increased considerably from 1990 (59 000 ha) to 2017 (above 1215500 ha).

The Fusarium species can be isolated from cereal kernels and identified using classical and/or molecular methods (Wiśniewska et al. 2014). The molecular method widely used for identification and quantification of Fusarium DNA concentration in samples is real time PCR (Niessen 2007; Nicolaisen et al. 2009; Nielsen et al. 2011, 2013; Horevaj et al. 2011).
The aim of the present study was to determine the presence Fusarium species and content of mycotoxins in wheat grain in Poland, Samples were collected in 2009 and 2010. Results were compared with Fusarium species frequency reported earlier and the results obtained after 2010 .

\section{Material and methods Cereal grain samples}

Fifty samples of wheat grain were collected during the harvesting season 2010. They originated from 25 experimental stations of COBORU (the Research Centre for Cultivar Testing) located in different regions of Poland (Figure 1; marked with numbers). Two winter wheat cultivars 'Bogatka' (medium resistant to FHB) and 'Muszelka' (susceptible) were included. The winter wheat was grown with a moderate nitrogen input (avg. 90 $\mathrm{kg} / \mathrm{ha}$ of $\mathrm{N}$ ) and without chemical control of diseases. The grain was harvested using combine harvester.

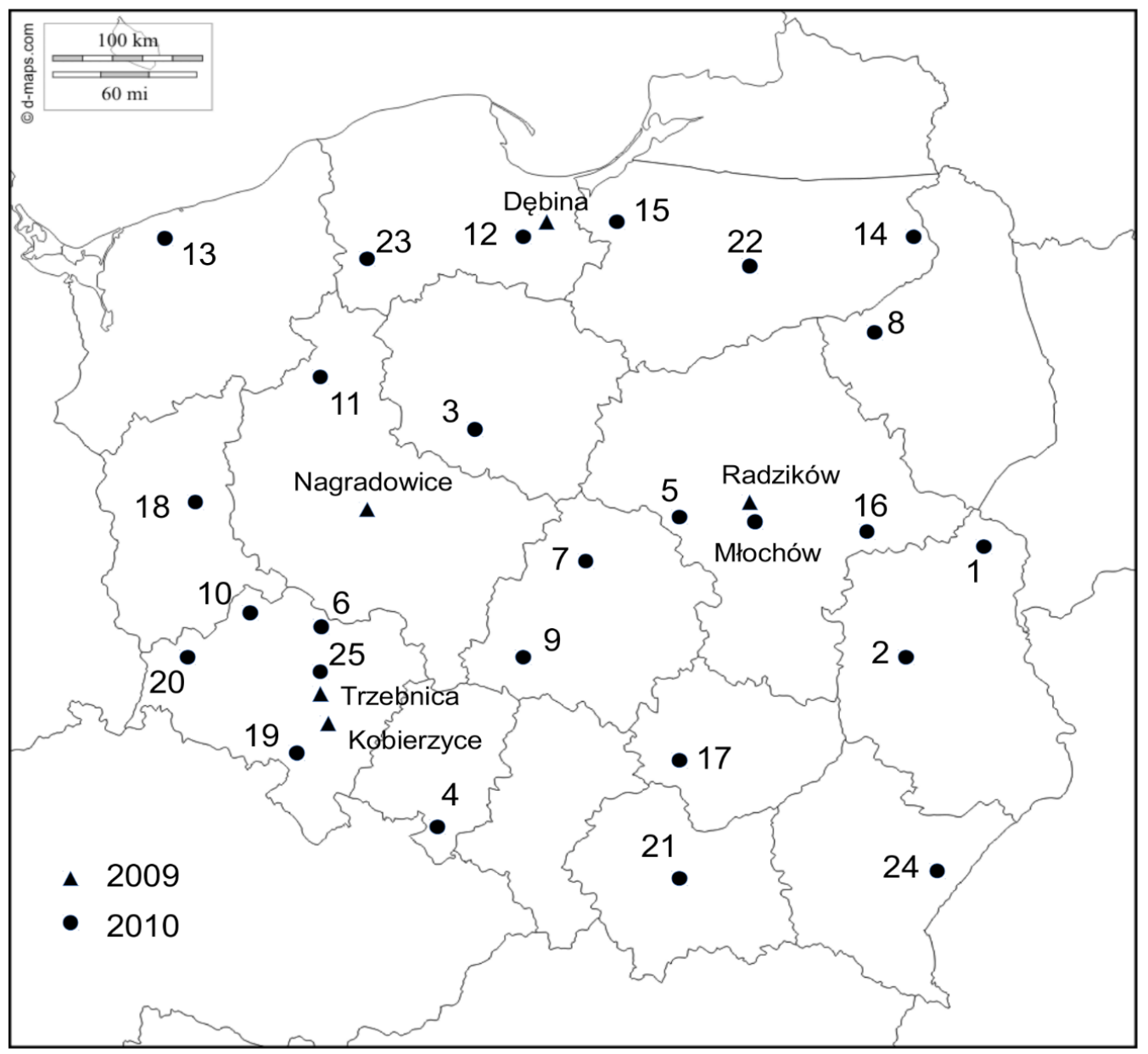

Figure 1. Map of Poland showing locations of sample collection of winter and spring wheat grain in 2009 (triangles) and 2010 (circles). Location numbers correspond to these in Table 2

Rysunek 1. Mapa Polski pokazująca miejsca pochodzenia prób ziarna pszenicy ozimej i jarej w latach 2009 (trójkąty) i 2010 (kółka). Numery miejscowości odpowiadają numerom w Tabeli 2 
Additionally, 11 samples of wheat grain from 2009 (5 locations) and 8 samples from 2010 (2 locations) were analyzed. Samples were collected from different locations/fields and cultivars of spring and winter wheat (Figure 1, Table 1, Table 4).

Wheat grain samples were stored in a freezer at $-20^{\circ} \mathrm{C}$ before DNA and mycotoxins extraction.

\section{DNA extraction and analysis}

Grain samples of $300 \mathrm{~g}$ were initially ground with a laboratory grinder and $5 \mathrm{~g}$ was powdered in liquid $\mathrm{N}_{2}$ with eight steel balls using Geno/Grinder 2000 (OPS Diagnostics, Bridgewater, NJ). DNA was extracted from $100 \mathrm{mg}$ of that powdered sample using a modified CTAB method (http://gmo-crl.jrc. ec.europa.eu/summaries/NK603-WEB-ProtocolValidation.pdf) as described by Nicolaisen et al. (2009). DNA extracted from the wheat samples was further purified using a DNeasy kit (Qiagen) according to the manufacturer's instructions.

The Fusarium isolates: F. avenaceum 9605, F. culmorum 9560, F. equiseti 8752, F. graminearum 1955, $F$. langsethiae $8051, F$. poae 8452 , F. sporotrichioides 1926, and F. tricinctum 8048 were grown and extracted as described in Nielsen et al. (2011). They were grown on potato dextrose agar (PDA) medium at $22^{\circ} \mathrm{C}$ under $12 \mathrm{~h}$ of light and $12 \mathrm{~h}$ of darkness for 1-2 weeks prior to DNA extraction. PDA plates before inoculation were covered with sterile cellophane membranes (Horevaj et al. 2011). Mycelium was scraped off the cellophane membrane using a spatula and ground in liquid $\mathrm{N}_{2}$ with eight steel balls using a Geno/ Grinder 2000 (OPS Diagnostics, Bridgewater, NJ). Powdered mycelium (100 mg) was used for DNA extraction, using the same method as for grain samples. The concentration of DNA from Fusari$u m$ isolates was determined using NanoDrop 1000 (Thermo Fisher Scientific, MA).

Qualitative and quantitative determinations of eight Fusarium species in grain were performed by real time-PCR. Primers used were based on fungal TEF-1 $\alpha$ gene sequences, designed by Nicolaisen et al. (2009), specific for the different Fusarium species: $F$. avenaceum, $F$. culmorum, $F$. equiseti, $F$. graminearum, $F$. langsethiae, $F$. poae, F. sporotrichioides, and F. tricinctum.

Real-time PCR was carried out in $12.5 \mu$ l consisting of $6.25 \mu \mathrm{l}$ of $2 \times$ SYBR Green PCR Master Mix (Applied Biosystems), $250 \mathrm{nM}$ each primer, bovine serum albumin at $0.5 \mu \mathrm{g} / \mu \mathrm{l}$, and $2.5 \mu \mathrm{l}$ of template DNA. PCR reactions were performed in duplicate on all samples. Genomic DNA from grain samples and pure cultures was diluted 1:10 before PCR.
PCR was performed on a 7900HT Sequence Detection System (Applied Biosystems) using the following cycling protocol: $2 \mathrm{~min}$ at $50^{\circ} \mathrm{C}$; $95^{\circ} \mathrm{C}$ for $10 \mathrm{~min} ; 40$ cycles of $95^{\circ} \mathrm{C}$ for $15 \mathrm{~s}$ and $62^{\circ} \mathrm{C}$ for $1 \mathrm{~min}$; followed by dissociation analysis at 60 to $95^{\circ} \mathrm{C}$. For the plant assay annealing and extension was performed at $60{ }^{\circ} \mathrm{C}$. Standard curves for Fusarium species and wheat were made of five-fold dilution series using pure fungal DNA and wheat DNA. The amount of fungal DNA was calculated from the cycle threshold $(\mathrm{Ct})$ values using the standard curve. The result of each individual sample from each species-specific assay were evaluated by studying the dissociation curve and $\mathrm{Ct}$ value, as SYBR Green binds to all double stranded DNA and might create false positives. The plant EF1 $\alpha$ assay was used to provide a normalized measurement for Fusarium DNA in each sample, which was calculated as picograms of fungal DNA per micrograms of plant DNA according to Nicolaisen et al. (2009).

\section{Analysis of Fusarium toxins}

The type B trichothecenes - deoxynivalenol (DON), nivalenol (NIV) were quantified using gas chromatography with electron capture detection (GC-ECD) technique. Mycotoxins were extracted from $5 \mathrm{~g}$ of ground grains using $25 \mathrm{ml}$ of an aqueous solution of acetonitrile (acetonitrile: water 84:16) in a shaker $90 \mathrm{~min}, 300$ r.p.m..

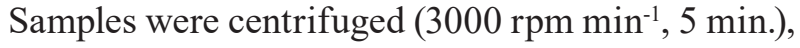
and the extract was purified with MycoSep ${ }^{\circledR}$ 227 Trich + columns (Romer Labs Inc., Union, $\mathrm{MO})$. One milliliter of the internal standard solution (chloralose) was added to $4 \mathrm{ml}$ of purified extract. The solvent was evaporated to dryness in the stream of air. Mycotoxins were derivatized to the trimethylsilyl derivatives using a derivatizing agent Sylon BTZ (BSA + TMCS + TMSI, 3: 2: 3, Supelco). After dissolution of sample in isooctane, excess of derivatizing agent was decomposed and removed with water. The organic layer was transferred to autosampler vial and analyzed chromatographically with gas chromatograph SRI $8610 \mathrm{C}$, with BGB-5MS column of $30 \mathrm{~m}$ in length, and an internal diameter of $0.25 \mathrm{~mm}$.

The carrier gas was hydrogen, adjusted to pressure $12 \mathrm{psi}$, with nitrogen as a make-up gas at 60 $\mathrm{mL} / \mathrm{min}$. Elution was carried out in the temperature gradient: Initial temperature was $170^{\circ} \mathrm{C}$, increased to $250{ }^{\circ} \mathrm{C}$ at $5{ }^{\circ} \mathrm{C} / \mathrm{min}$., and increased from $250{ }^{\circ} \mathrm{C}$ to $300{ }^{\circ} \mathrm{C}$ at $10^{\circ} \mathrm{C} / \mathrm{min}$., followed by a holding time of $5 \mathrm{~min}$., and decreased to $170^{\circ} \mathrm{C}$. Mycotoxin detection was carried out using electron capture detector 
(ECD). Identification of individual compounds was made by comparing the retention times of the pure standards of mycotoxins. The concentration of mycotoxins was established based on the calibration curve, using chloralose as the internal standard. Results were corrected for recoveries, ranged from $73 \%$ (NIV) to $85 \%$ (DON). The limits of detection (LOD) was on average $5 \mu \mathrm{g} / \mathrm{kg}$, and limit of quantification $10 \mu \mathrm{g} / \mathrm{kg}$.

The content of zearalenone (ZEN) was determined using a quantitative direct competitive enzyme-linked immunosorbent assay (ELISA) AgraQuant ${ }^{\circledR}$ ZON 25/1000 (Romer Laboratories). (LOD $10 \mu \mathrm{g} / \mathrm{kg}$, LOQ $25 \mu \mathrm{g} / \mathrm{kg}$ ). Based on results of reference sample (Quality Control Material, Biopure, Austria), correction for recovery was not applied.

\section{Statistical analysis}

The original Fusarium DNA and toxin concentrations were transformed to logarithmic values to obtain a normal distribution for the variables. The relationships between the results for Fusarium DNA and Fusarium toxins were investigated by Pearson correlation tests. Principal component analysis was used to analyze relationship between concentrations of DNA of $F$. avenaceum, $F$. culmorum, $F$. graminearum, $F$. langsethiae and $F$. poae in grain samples from 25 locations. Next, PCA was applied to analyze relationship between concentrations of Fusarium toxins (DON, NIV, ZEN) and DNA of producing species $F$. culmorum, $F$. graminearum and $F$. poae in grain samples from 25 locations. The correlation and PCA analyses were performed using Microsoft ${ }^{\circledR}$ Excel 2010/ XLSTAT@-Pro (Version 2013.4.07, Addinsoft, Inc., Brooklyn, NY, USA).

\section{Results \\ Samples from 2009}

In 2009, the highest amount of Fusarium DNA was found in the grain of spring wheat 'Griwa' (Radzików 1) and winter wheat 'Muszelka' (Dębina 2), which is highly susceptible to FHB (Table 1). The lowest amounts were detected in the grain of winter wheat cultivars 'Zawisza' (Radzików 6) and 'Tonacja' (Radzików 5) and in spring wheat 'Raweta' (Radzików 3).

Table 1

Tabela 1

Concentration of Fusarium species DNA and DON, NIV and ZEN mycotoxins levels in samples of grain of spring and winter wheat collected in 2009

Zawartość DNA gatunków Fusarium oraz mykotoksyn DON, NIV i ZEN w próbach ziarna pszenicy jarej i ozimej zebranych w 2009 r.

\begin{tabular}{|c|c|c|c|c|c|c|c|c|}
\hline \multirow{2}{*}{$\begin{array}{l}\text { No. } \\
\text { Lp. }\end{array}$} & \multirow{2}{*}{$\begin{array}{l}\text { Sample name } \\
\text { Próba }\end{array}$} & \multicolumn{4}{|c|}{ Fusarium DNA $(\mathrm{pg} / \mu \mathrm{g})^{\text {a }}$} & \multirow{2}{*}{$\begin{array}{c}\text { DON } \\
(\mu \mathrm{g} / \mathrm{kg})\end{array}$} & \multirow{2}{*}{$\begin{array}{c}\text { NIV } \\
(\mu \mathrm{g} / \mathrm{kg})\end{array}$} & \multirow{2}{*}{$\begin{array}{c}\text { ZEN } \\
(\mu \mathrm{g} / \mathrm{kg})\end{array}$} \\
\hline & & $\mathrm{Fa}$ & $F c$ & $\mathrm{Fg}$ & $F p$ & & & \\
\hline 1 & Radzików $1^{\text {b }}$ & 1300 & 153 & 60248 & 70 & 5719 & 43 & 63 \\
\hline 2 & Radzików $2^{\mathrm{b}}$ & 89 & 41 & 21804 & 0 & 2020 & 0 & 25 \\
\hline 3 & Radzików $3^{\text {b }}$ & 53 & 31 & 911 & 9 & 104 & 0 & 0 \\
\hline 4 & Dębina 1 & 0 & 316 & 18966 & 63 & 2937 & 45 & 78 \\
\hline 5 & Dębina $2^{c}$ & 533 & 8862 & 46102 & 287 & 7170 & 281 & 29 \\
\hline 6 & Kobierzyce & 0 & 387 & 26384 & 949 & $\mathrm{n} / \mathrm{a}$ & $\mathrm{n} / \mathrm{a}$ & $\mathrm{n} / \mathrm{a}$ \\
\hline 7 & Nagradowice $^{c}$ & 366 & 22949 & 5462 & 67 & 9239 & 33 & 230 \\
\hline 8 & Radzików 4 & 0 & 34 & 4277 & 137 & 658 & 177 & 0 \\
\hline 9 & Radzików 5 & 63 & 38 & 2115 & 187 & 213 & 36 & 12 \\
\hline 10 & Radzików 6 & 0 & 0 & 207 & 33 & 47 & 0 & 17 \\
\hline \multirow[t]{2}{*}{11} & Trzebnica & 1753 & 252 & 2044 & 285 & 123 & 61 & 0 \\
\hline & Mean Średnia & 378 & 3006 & 17138 & 190 & 2823 & 68 & 45 \\
\hline
\end{tabular}

a - F. langsethiae, F. sporotrichioides and F. tricinctum were excluded; ${ }^{b}-$ spring wheat; ${ }^{c}$ - grain from collected symptomatic spikes; $F a=F$. avenaceum, $F c=F$. culmorum, $F g=F$ graminearum, $F p=F$. poae; $\mathrm{n} / \mathrm{a}-$ not analysed

${ }^{\mathrm{a}}-F$. langsethiae, $F$. sporotrichioides i $F$. tricinctum nie zostały pokazane; ${ }^{\mathrm{b}}-$ pszenica jara; ${ }^{\mathrm{c}}-\mathrm{ziarno} \mathrm{z}$ kłosów z objawami fuzariozy; $F a=F$. avenaceum, $F c=F$. culmorum, $F g=F$. graminearum, $F p=F$. poae; $\mathrm{n} / \mathrm{a}-$ nie analizowane 
Of the eight Fusarium species tested, seven were detected in wheat grain, except for F. langsethiae. Fusarium graminearum was present in all samples, F. poae and F. culmorum in ten samples $(91 \%)$, F. avenaceum in seven samples (64\%). Fusarium sporotrichioides and $F$. tricinctum were found in two individual samples: first species in sample 'Radzików 1' at $69 \mathrm{pg} / \mu \mathrm{g}$, and the second in wheat grain from Dębina ('Dębina 2') at $428 \mathrm{pg} / \mu \mathrm{g}$. Traces of $F$. equiseti were found in two samples ('Dębina 2', 'Nagradowice').

Despite large differences in Fusarium DNA content in the grain samples, amount of $F$. graminearum DNA was the highest in nine samples (Figure 2). F. culmorum dominated only in a sample from Nagradowice and in sample from Trzebnica concentrations of $F$. avenaceum and $F$. graminearum DNA were similar.

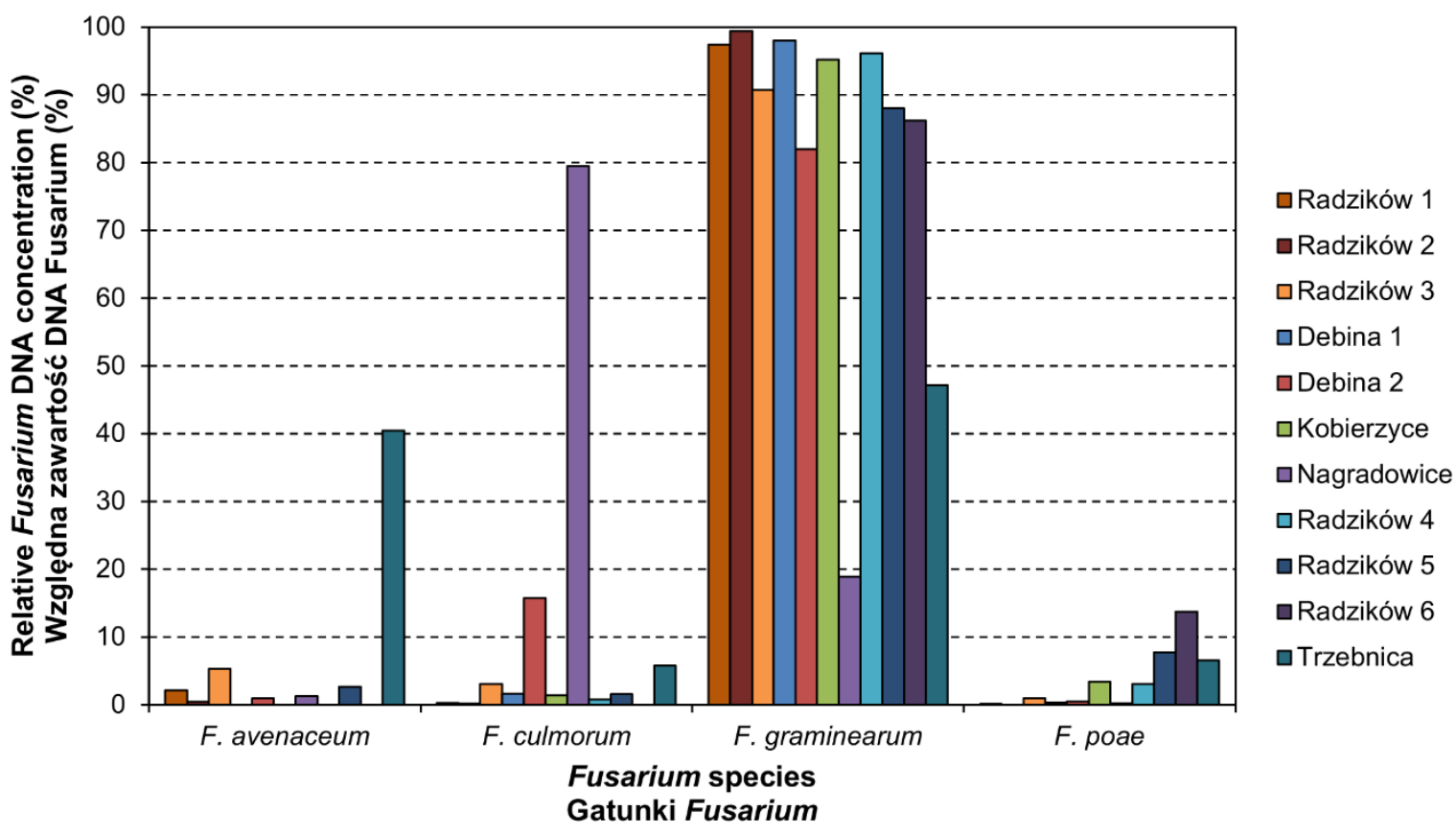

Figure 2. Relative concentration of DNA of four Fusarium species in 11 samples of spring and winter wheat collected in 2009. F. equiseti, $F$. sporotrichioides and $F$. tricinctum were excluded

Rysunek 2. Względna zawartość DNA czterech gatunków Fusarium w 11 próbach pszenicy jarej i ozimej zebranych w 2009 r. F. equiseti, F. sporotrichioides i F. tricinctum nie zostały włączone

DON was detected in all analysed samples at the average level of $2823 \mu \mathrm{g} / \mathrm{kg}$ (Table 1). The most contaminated were the grain samples of winter wheat 'Nagradowice' and 'Debina 2' and spring wheat 'Radzików 1'. Levels of NIV were much lower. On average, it was $68 \mu \mathrm{g} / \mathrm{kg}$. NIV was detected in seven samples. The highest concentration was in the grain of winter wheat from 'Debina 2 ' and winter wheat 'Radzików 4'. ZEN was detected in six samples at the average level of $45 \mu \mathrm{g} /$ $\mathrm{kg}$. Considerable amounts of ZEN were found in samples from Nagradowice and in samples of spring wheat 'Radzików 1' and winter wheat 'Dębinal'.

DON concentration correlated significantly with total Fusarium DNA $(\mathrm{r}=0.947, p<0.001)$, for NIV and ZEN coefficients were insignificant $(\mathrm{r}=0.537, p=0.109$ and $\mathrm{r}=0.561, p=0.092$, respectively). When looking at individual species, high correlation between DON and DNA of F. graminearum and $F$. culmorum were evident $(\mathrm{r}=0.885$, $p=0.001$ and $\mathrm{r}=0.740, p=0.014$, respectively). As regards NIV, significant correlation was observed with $F$. poae DNA $(\mathrm{r}=0.875, p=0.001)$.

\section{Samples from 2010}

In 2010, average concentration of Fusarium

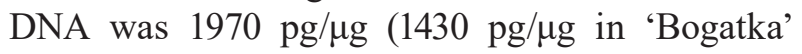
grain and $3770 \mathrm{pg} / \mu \mathrm{g}$ in 'Muszelka' grain) (Table 2). The difference in Fusarium DNA concentration between cultivars was statistically significant according to paired samples t-test. The highest concentration of DNA was detected in the grain from Zadąbrowie, South-Eastern Poland (Figure 1). The DNA amount was five-six times lower in the grain from Czesławice (South-Eastern Poland), Rychliki, Radostowo (Northern PL) and Głubczyce (Southern PL). Very low concentration of DNA was 
BIULETYN IHAR Nr 296 / 2021 Species of the genus Fusarium and Fusarium toxins in the grain of winter and spring wheat in Poland

found in the grain from Naroczyce, Nowa Wieś Ujska was observed in the grain from South-Eastern (Western Poland), Kawęczyn (Central Poland), and North-Eastern Poland and the lowest concenand Rarwino (North-Western Poland). At a region- trations was observed in the grain from Western, al scale, the highest Fusarium DNA concentration North-Western and Central Poland (Figure 1).

Table 2

Tabela 2

Concentration of total Fusarium DNA, and DON, NIV and ZEN mycotoxins levels in grain of winter wheat cultivars 'Bogatka' and 'Muszelka' from 2010 harvest

Sumaryczne stężenie DNA Fusarium oraz zawartość mykotoksyn DON, NIV i ZEN w ziarnie odmian pszenicy ozimej Bogatka i Muszelka ze zbiorów w 2010 r.

\begin{tabular}{|c|c|c|c|c|c|c|c|c|c|}
\hline \multirow{2}{*}{$\begin{array}{l}\text { No. } \\
\text { Lp. }\end{array}$} & \multirow{2}{*}{$\begin{array}{l}\text { Location } \\
\text { Miejscowość }\end{array}$} & \multicolumn{2}{|c|}{$\begin{array}{l}\text { Fusarium DNA } \\
(\mathrm{pg} / \mu \mathrm{g})^{\mathrm{a}}\end{array}$} & \multicolumn{2}{|c|}{$\begin{array}{l}\text { DON } \\
(\mu \mathrm{g} / \mathrm{kg})\end{array}$} & \multicolumn{2}{|c|}{$\begin{array}{l}\text { NIV } \\
(\mu \mathrm{g} / \mathrm{kg})\end{array}$} & \multicolumn{2}{|c|}{$\begin{array}{c}\text { ZEN } \\
(\mu \mathrm{g} / \mathrm{kg})\end{array}$} \\
\hline & & $\begin{array}{c}\text { Mean } \\
\text { Średnia }\end{array}$ & SD & $\begin{array}{c}\text { Mean } \\
\text { Średnia }\end{array}$ & SD & $\begin{array}{l}\text { Mean } \\
\text { Średnia }\end{array}$ & SD & $\begin{array}{l}\text { Mean } \\
\text { Srednia }\end{array}$ & $\mathrm{SD}$ \\
\hline 1 & Cicibór & 2295 & 620 & 76.3 & 7.6 & 53.7 & 0.4 & 17.9 & 17.9 \\
\hline 2 & Czesławice & 4126 & 1319 & 181.4 & 37.4 & 63.7 & 0.0 & 93.1 & 35.2 \\
\hline 3 & Głębokie & 842 & 203 & 63.5 & 7.4 & 59.5 & 1.1 & 18.1 & 18.1 \\
\hline 4 & Głubczyce & 2919 & 969 & 127.2 & 35.5 & 60.7 & 5.6 & 26.8 & 26.8 \\
\hline 5 & Kawęczyn & 55 & 54 & 61.1 & 2.9 & 51.8 & 1.6 & 0 & 0 \\
\hline 6 & $\begin{array}{l}\text { Krościna } \\
\text { Mała }\end{array}$ & 1327 & 1276 & 61.0 & 7.1 & 52.2 & 0.5 & 0 & 0 \\
\hline 7 & Lućmierz & 315 & 36 & 110.7 & 54.3 & 61.5 & 8.0 & 0 & 0 \\
\hline 8 & Marianowo & 1743 & 948 & 53.3 & 1.4 & 52.1 & 0.1 & 0 & 0 \\
\hline 9 & Masłowice & 650 & 203 & 65.3 & 9.4 & 51.7 & 1.7 & 10.6 & 10.6 \\
\hline 10 & Naroczyce & 38 & 38 & 63.0 & 5.3 & 50.8 & 1.9 & 9.9 & 9.9 \\
\hline 11 & $\begin{array}{l}\text { Nowa Wieś } \\
\text { Ujska }\end{array}$ & 65 & 65 & 51.9 & 1.7 & 50.3 & 1.1 & 10,1 & 10.1 \\
\hline 12 & Radostowo & 3466 & 1428 & 58.6 & 1.9 & 53.0 & 0.2 & 0 & 0 \\
\hline 13 & Rarwino & 108 & 108 & 53.5 & 3.3 & 52.8 & 1.1 & 0 & 0 \\
\hline 14 & Ruska Wieś & 951 & 73 & 55.4 & 2.7 & 51.8 & 0.7 & 13.5 & 13.5 \\
\hline 15 & Rychliki & 3230 & 2138 & 87.9 & 9.2 & 54.3 & 0.6 & 42.0 & 21.5 \\
\hline 16 & Seroczyn & 731 & 731 & 78.1 & 15.0 & 54.6 & 3.4 & 27.6 & 27.6 \\
\hline 17 & Słupia & 1116 & 474 & 107.3 & 27.7 & 53.6 & 3.7 & 36.9 & 36.9 \\
\hline 18 & Świebodzin & 303 & 165 & 51.2 & 1.8 & 51.9 & 0.2 & 13.8 & 13.8 \\
\hline 19 & Tarnów & 1213 & 14 & 89.1 & 28.5 & 54.8 & 4.5 & 0 & 0 \\
\hline 20 & $\begin{array}{l}\text { Tomaszów } \\
\text { Boles. }\end{array}$ & 231 & 148 & 76.3 & 3.5 & 55.1 & 0.2 & 0 & 0 \\
\hline 21 & Węgrzce & 927 & 451 & 86.9 & 7.2 & 56.5 & 3.3 & 20.1 & 20.1 \\
\hline 22 & Wrócikowo & 1679 & 723 & 165.8 & 96.7 & 61.6 & 9.2 & 0 & 0 \\
\hline 23 & Wyczechy & 645 & 288 & 83.0 & 24.0 & 56.7 & 5.4 & 0 & 0 \\
\hline 24 & Zadąbrowie & 19269 & 6931 & 420.3 & 131.7 & 57.7 & 1.3 & 227.0 & 21.3 \\
\hline 25 & Zybiszów & 1017 & 97 & 76.9 & 12.4 & 56.6 & 0.6 & 29.3 & 29.3 \\
\hline \multicolumn{2}{|c|}{ Mean Średnia } & 1970 & - & 96.2 & - & 55.2 & - & 23.9 & - \\
\hline \multicolumn{2}{|c|}{$\begin{array}{c}\text { Mean Średnia 'Bo- } \\
\text { gatka' }\end{array}$} & 1430 & - & 78.2 & - & 53.4 & - & 11.4 & - \\
\hline \multicolumn{2}{|c|}{$\begin{array}{l}\text { Mean Średnia 'Mu- } \\
\text { szelka' }\end{array}$} & 3770 & - & 114.2 & - & 56.9 & - & 36.3 & - \\
\hline
\end{tabular}

a - sum of DNA of detected Fusarium species

a - suma DNA wykrytych gatunków Fusarium 
Of the eight Fusarium species tested, five were detected in wheat grain. DNA of $F$. equiseti, $F$. sporotrichioides and $F$. tricinctum was not detected in any sample. The highest was the content of $F$. graminearum DNA $(1252 \mathrm{pg} / \mu \mathrm{g})$, then $F$. avenaceum $(259 \mathrm{pg} /$ $\mu \mathrm{g}), F$. langsethiae $(237 \mathrm{pg} / \mu \mathrm{g})$ and $F$. poae $(168 \mathrm{pg} / \mu \mathrm{g})$ (Figure 3). The content of F. culmo-

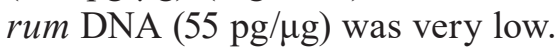

The most frequently occurring species were $\mathrm{pg} / \mu \mathrm{g}$ ).

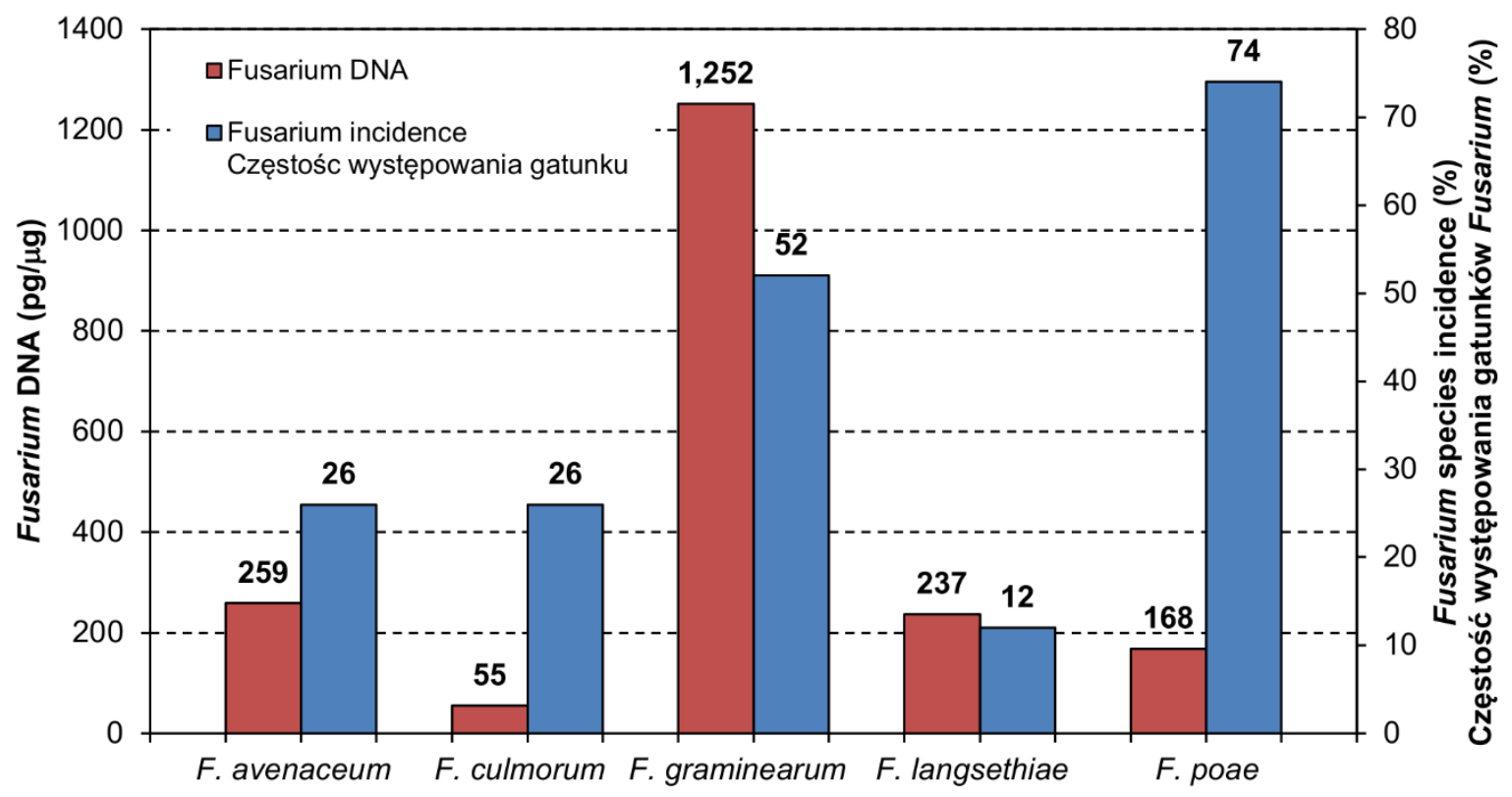

Fusarium species

Gatunki Fusarium

Figure 3. Average concentration of DNA (pg of fungal DNA/mg of wheat DNA) and incidence (percentages) of five Fusarium species in $\mathbf{5 0}$ samples of winter wheat collected in Poland in 2010

Rysunek 3. Średnie stężenie DNA (pg DNA Fusarium/ug DNA pszenicy) i częstość występowania (procent) pięciu gatunków Fusarium w 50 próbach pszenicy ozimej zebranych w Polsce w 2010 r.

$F$. poae was detected in all samples of medium resistant cultivar 'Bogatka' but only in $48 \%$ of samples of susceptible 'Muszelka'. Another species $F$. avenaceum was also found more frequently in the grain of 'Bogatka' (32\%) than 'Muszelka' (20\%). Three other species (F. culmorum, $F$. graminearum, F. langsethiae) were detected in the grain of both cultivars with similar frequency.

Amounts of DNA of Fusarium species weakly correlated with each other. Only coefficient of correlation of $F$. graminearum with. $F$. culmorum was statistically significant $(\mathrm{r}=0.461, p=0.02)$. Positive relationship was found between $F$. avenaceum and F. culmorum or F. graminearum $(\mathrm{r}=0.306$, $\mathrm{r}=0.162)$ as DNA of the first species was mostly detected in the same locations as the other two species $-1,4,14,19,22$ (only $F$. graminearum), and 24. DNA of $F$. langsethiae did not correlate with other species, as it was found only in six samples. Otherwise, F. poae DNA did not correlate with other species because the species was present in the most of samples (74\%) and in the most samples (except two) amounts of $F$. poae DNA were similar.

Biplot produced by PCA analysis on DNA concentration of five Fusarium species showed uneven distribution of these species in different locations (Figure 4). F. culmorum was present mostly in the same locations as $F$. graminearum (except 12). F. avenaceum was present in the same six locations as $F$. culmorum and $F$. graminearum (except 22 , where only the second species was detected). In three locations $(7,8,13)$ this species was 
accompanied only by $F$. poae. As it was mentioned earlier, $F$. langsethiae was found in four locations $(12,15,17,23)$. In Słupia (17) it was accompanied by $F$. culmorum and $F$. graminearum, in Radostowo (12) and Rychliki (15) by F. culmorum or F. graminearum, respectively.

\section{Biplot (axes D1 and D2: 56,75 \%) after Varimax rotation}

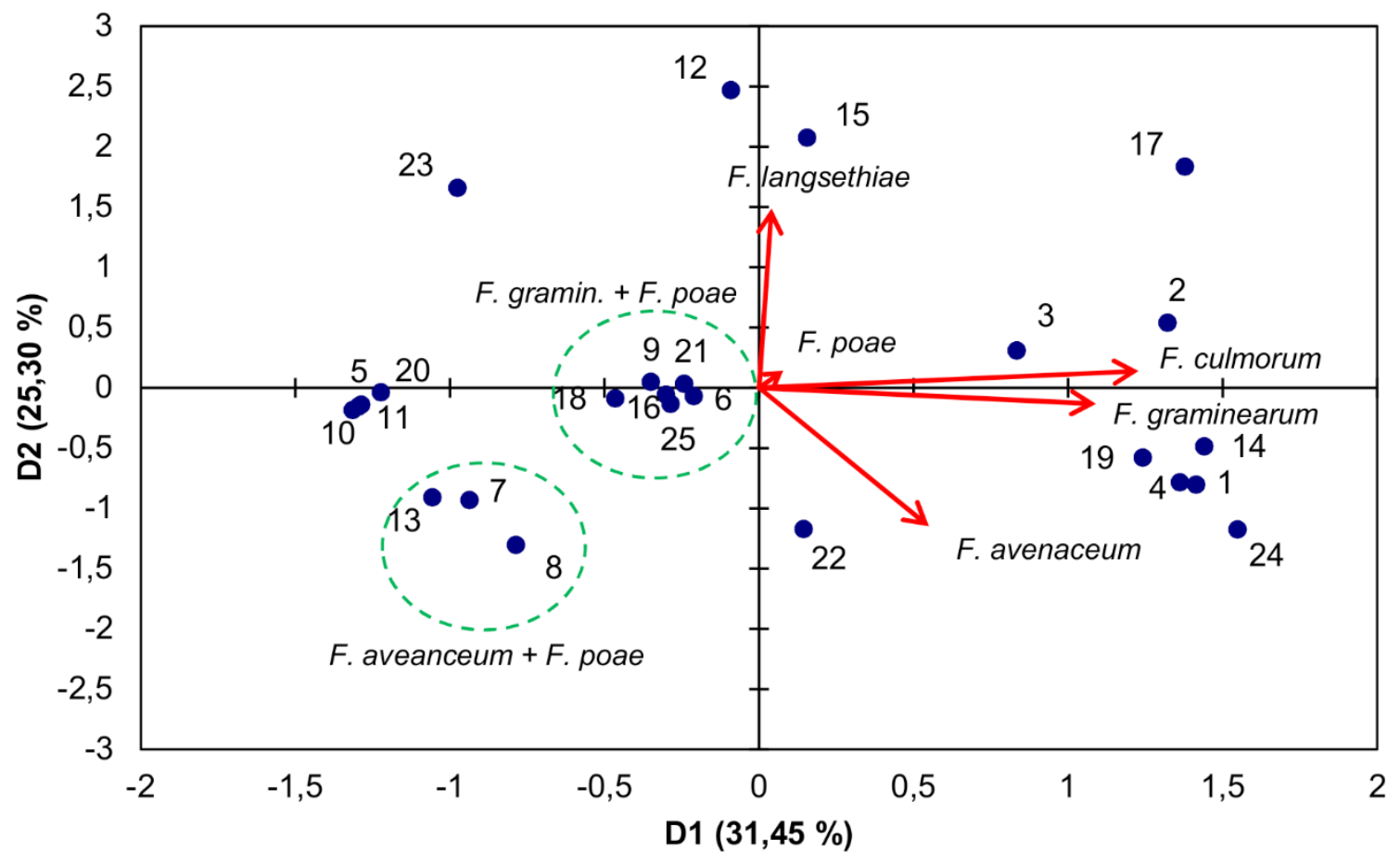

Figure 4. Principal Component Analysis based on DNA of Fusarium avenaceum, F. culmorum, F. graminearum, $F$. langsethiae and $F$. poae in grain samples of winter wheat collected from 25 locations in Poland in 2010. Location numbers correspond to those in table 3 . Variables were log transformed prior to the analysis

Rysunek 4. Analiza składowych głównych dla zawartości DNA Fusarium avenaceum, F. culmorum, F. graminearum, $F$. langsethiae i $F$. poae w próbach ziarna pszenicy ozimej zebranych z 25 lokalizacji w Polsce w 2010 roku. Numery lokalizacji odpowiadają numerom w Tabeli 3. Zmienne zostały przekształcone logarytmicznie przed analizą

Average content of DON was low and amounted to $96.2 \mu \mathrm{g} / \mathrm{kg}$, at a range from. 49.3 to $552.0 \mu \mathrm{g} /$ $\mathrm{kg}$ (Table 3). The content of NIV was very low $55.2 \mu \mathrm{g} / \mathrm{kg}$, at a range $49.2-70.8 \mu \mathrm{g} / \mathrm{kg}$. The average content of DON for 'Bogatka' was $78.2 \mu \mathrm{g} / \mathrm{kg}$, and $114.2 \mu \mathrm{g} / \mathrm{kg}$ for 'Muszelka'. Difference of DON content between cultivars was not statistically significant. The highest concentration of DON was found in samples of both cultivars from Zadąbrowie and Czesławice, South-Eastern Poland (Figure 1). High concentration of this toxin was also found in the samples of 'Muszelka' from Wrócikowo, Lućmierz and Głubczyce.

ZEN was detected in $12 \%$ of samples of 'Bogat$\mathrm{ka}$ ' and in $60 \%$ of samples of 'Muszelka' cultivars. Average content was $23.9 \mu \mathrm{g} / \mathrm{kg}$ and was 3 times higher in the grain of 'Muszelka' than in 'Bogatka'. The difference in ZEN content between cultivars was statistically significant according to paired samples t-test. High concentration of ZEN was present in samples of 'Muszelka' and 'Bogatka' grain from Zadąbrowie ( 248 and $206 \mu \mathrm{g} / \mathrm{kg}$, respectively) and in 'Muszelka' sample from Czesławice $(128 \mu \mathrm{g} / \mathrm{kg})$.

Six samples of the grain containing DNA of $F$. langsethiae were analyzed for T-2/HT-2 toxins. In all the samples, the total concentration of both mycotoxins was below detection limit of $35 \mu \mathrm{g} / \mathrm{kg}$.

Amount of Fusarium DNA in grain correlated significantly with concentration of Fusarium toxins (DON, NIV, ZEN) (Table 3). F. graminearum DNA correlated significantly with DON and ZEN concentrations, whereas $F$. culmorum DNA with ZEN concentration only. DNA of $F$. poae did not correlate with DON and ZEN - toxins not produced by this species. There was some positive relationship between $F$. poae and NIV concentration. Summarized amount of $F$. culmorum and $F$. graminearum DNA did not improve the strength of correlation with the toxins. Correlation of NIV with F. graminearum $+F$. poae DNA (possible NIV producers) was statistically significant $(\mathrm{r}=0.511)$. 
Coefficients of correlation between concentration of DNA (pg/ $/ \mathrm{gg})$ of three Fusarium species and concentration $(\mu \mathrm{g} / \mathrm{kg})$ of mycotoxins DON, NIV and ZEN in grain of winter wheat cultivars 'Bogatka' and 'Muszelka' from 2010 harvest in 25 locations

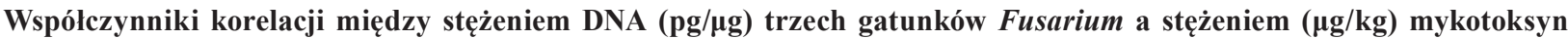
DON, NIV i ZEN w ziarnach odmian pszenicy ozimej Bogatka i Muszelka ze zbiorów w 2010 r. w 25 lokalizacjach

\begin{tabular}{ccccccccc}
\hline $\mathrm{n}=25$ & $\boldsymbol{F u s a r i u m}$ & $\boldsymbol{F g}$ & $\boldsymbol{F} \boldsymbol{c}$ & $\boldsymbol{F g}+\boldsymbol{F} \boldsymbol{c}$ & $\boldsymbol{F}$. poae & DON & NIV & ZEN \\
\hline DON & 0.622 & 0.534 & 0.320 & 0.509 & - & & & \\
NIV & 0.467 & 0.381 & 0.242 & 0.354 & 0.300 & 0.695 & & \\
ZEN & 0.400 & 0.672 & 0.406 & 0.658 & - & 0.438 & 0.186 & \\
$\begin{array}{c}\text { Toxins } \\
\text { Toksyny }\end{array}$ & 0.649 & 0.609 & 0.365 & 0.587 & -0.035 & 0.974 & 0.643 & 0.612 \\
\hline
\end{tabular}

Values in bold are different from 0 with a significance level of $\mathrm{P} \leq 0.05$; all variables were log transformed; Fg $-F$. graminearum, $F c-F$. culmorum, toxins - sum of DON, NIV and ZEN.

Wartości pogrubione różnią się od 0 na poziomie istotności $\mathrm{P} \leq 0,05$. Wszystkie zmienne zostały przekształcone logarytmicznie. $F g-F$. graminearum, $F c-F$. culmorum, toksyny - suma DON, NIV i ZEN.

Biplot produced by PCA analysis distinguished some locations based on concentrations of DNA of three Fusarium species and Fusarium toxins (Figure 5). In Zadąbrowie (24), we found the highest amount of DON and ZEN as well as amount of $F$. graminearum DNA. Grain from Czesławice (2) were characterized by the highest amounts of $F$. poae DNA and NIV but also have high concentrations of the others toxins/DNA. On the other hand, in Słupia (17) concentration of $F$. poae DNA and NIV was low, but analysis showed high concentration of F. culmorum accompanied by moderate concentration of F. graminearum and DON.

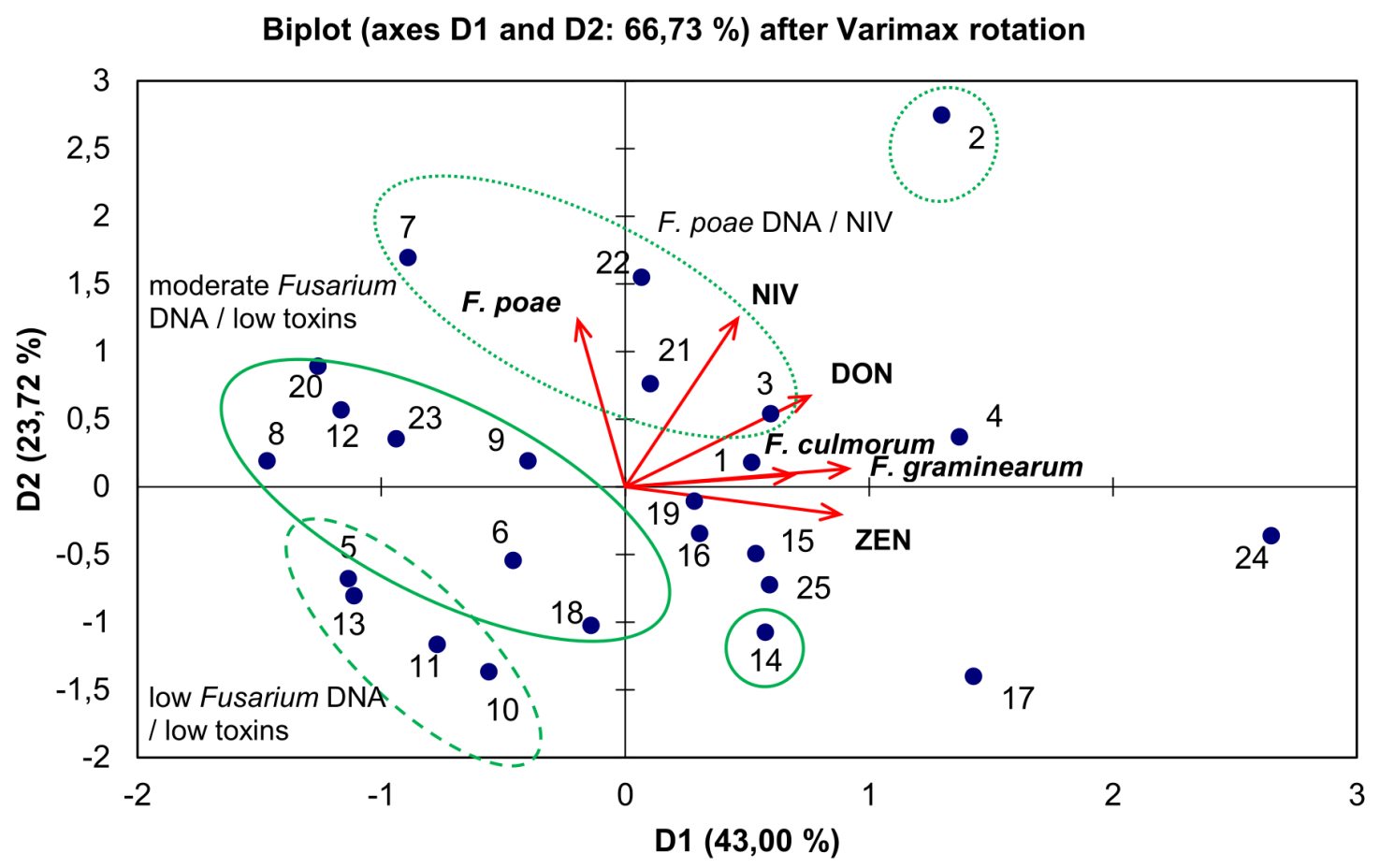

Figure 5. Principal Component Analysis based on DNA of Fusarium culmorum, F. graminearum and F. poae, and concentration of Fusarium toxins (DON, NIV, ZEN) in grain samples of winter wheat collected from 25 locations in Poland in 2010. Location numbers correspond to these in table 3 . Variables were log transformed prior to the analysis.

Rysunek 5. Analiza składowych glównych dla zawartości DNA Fusarium culmorum, F. graminearum i $F$. poae oraz stężenia toksyn fuzaryjnych (DON, NIV, ZEN) w próbach pszenicy ozimej pobranych z 25 miejsc w Polsce w 2010 r.

Numery lokalizacji odpowiadają numerom w Tabeli 3. Zmienne zostały przekształcone logarytmicznie przed analizą. 
In the four locations $(5,10,11,13)$ the concentration of DNA of three Fusarium species as well as the concentration of toxins were low. In another eight locations (Figure 5, solid line), concentration of toxins was low, but amount of Fusarium DNA varied from low (23) to high (6). In Ruska Wieś (14) we found the highest concentration of F. culmorum DNA (511.8 pg/ $\mu \mathrm{g})$. Five locations $(2,3,7,21$, and 22) could be characterized by above average concentration of NIV and moderate to high concentration of $F$. poae DNA. This species was present at considerable amounts also in samples from other locations $(1,8,9,12,20)$ but NIV concentration was low.

In samples of the grain of spring and winter wheat collected from Radzików and neighboring Młochów we found more Fusarium DNA than in most samples of 'Bogatka' and 'Muszelka' (Table 4). The highest amount of DNA was present in samples of winter wheat 'Tonac-

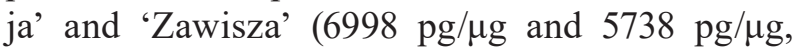
respectively). In spring wheat, it was lower, except for the sample of 'Raweta' from Radzików (Raweta R1) (5513 pg/ $\mu \mathrm{g})$.

Table 4

Tabela 4

Concentration of DNA of four Fusarium species, and DON and NIV mycotoxins levels in grain of spring and winter wheat from 2010 harvest in Radzików (R) and Młochów (M)

Zawartość DNA czterech gatunków Fusarium oraz toksyn fuzaryjnych DON i NIV w ziarnie pszenicy jarej i ozimej z 2010 r. w Radzikowie (R) i Młochowie (M)

\begin{tabular}{|c|c|c|c|c|c|c|c|}
\hline \multirow[t]{2}{*}{$\begin{array}{l}\text { No. } \\
\text { Lp. }\end{array}$} & \multirow[t]{2}{*}{$\begin{array}{c}\text { Cultivar (location) } \\
\text { Odmiana (lokalizacja) }\end{array}$} & \multicolumn{4}{|c|}{$\begin{array}{l}\text { Fusarium DNA } \\
(\mathrm{pg} / \mu \mathrm{g})\end{array}$} & \multicolumn{2}{|c|}{$\begin{array}{c}\text { Fusarium toxins } \\
(\mu \mathrm{g} / \mathrm{kg}) \\
\text { Toksyny fuzaryjne } \\
(\mu \mathrm{g} / \mathrm{kg})\end{array}$} \\
\hline & & $F a$ & $F c$ & $F \boldsymbol{F}$ & $F p$ & DON & NIV \\
\hline 1 & Griwa $(\mathrm{R})^{\mathrm{a}}$ & 587 & 70 & 1146 & 262 & 60,8 & 50,4 \\
\hline 2 & Parabola $(\mathrm{R})^{\mathrm{a}}$ & 874 & 65 & 257 & 59 & 58,1 & 50,9 \\
\hline 3 & Raweta (R) ${ }^{\mathrm{a}}$ & 0 & 57 & 379 & 58 & 61,6 & 50,0 \\
\hline 4 & Raweta (R1) $^{\mathrm{a}}$ & 3522 & 159 & 1671 & 161 & 92,1 & 51,1 \\
\hline 5 & Raweta $(\mathrm{M})^{\mathrm{a}}$ & 0 & 0 & 0 & 244 & 53,0 & 49,7 \\
\hline 6 & Tonacja (R) & 3223 & 0 & 2566 & 434 & 64,6 & 52,3 \\
\hline 7 & Tonacja (M) & 6169 & 0 & 0 & 829 & 54,5 & 50,9 \\
\hline \multirow[t]{2}{*}{8} & Zawisza (R) & 0 & 181 & 5441 & 116 & 135,3 & 52,6 \\
\hline & Mean Średnia & 1797 & 67 & 1432 & 270 & 72,5 & 51,0 \\
\hline
\end{tabular}

$F a=F$. avenaceum, $F c=F$. culmorum, $F g=F$. graminearum, $F p=F$. poae ${ }^{a}{ }^{a}-$ spring wheat

$F a=F$. avenaceum, $F c=F$. culmorum, $F g=F$. graminearum, $F p=F$. poae; ${ }^{a}-$ pszenica jara

Four Fusarium species were detected in grain. $F$. langsethiae and $F$. sporotrichioides were not present. F. avenaceum dominated in three samples (on average $1797 \mathrm{pg} / \mu \mathrm{g}$ of DNA) and $F$. graminearum in three $(1432 \mathrm{pg} / \mu \mathrm{g})$. In one sample (Tonacja R) amounts of DNA of these species were similar. $F$. poae was present in all samples of winter wheat $(270 \mathrm{pg} / \mu \mathrm{g})$. In the grain of spring, wheat 'Raweta' from Młochów only this species was present. The concentration of F. culmorum DNA was generally the lowest of all species $(67 \mathrm{pg} / \mu \mathrm{g})$.

The concentration of trichothecene toxins was low (Table 4). ZEN amount was below limit of detection. The highest concentration of DON was found in the samples with high concentration of $F$. graminearum and $F$. culmorum DNA - Zawisza R and Raweta R1. The same was true for NIV concentration in grain. No relation was found between $F$. poae and NIV; however, total concentration of $F$. graminearum and $F$. poae correlated the best with NIV amount.

\section{Discussion}

Presence and concentration of Fusarium DNA in naturally infected wheat in two years of the study was generally in accordance with data on occurrence of Fusarium species on wheat in Poland. According to the published data, dominant species on wheat spikes and kernels were $F$. culmorum, $F$. graminearum, $F$ avenaceum and $F$. poae (Perkowski et al. 1990; Goliński et al. 1996; Bottalico and Perrone 2002; Stępień et al. 2008; Chełkowski et al. 2012; Wiśniewska et al. 2014; Kuzdraliński et al. 2017; Bilska et al. 2018; Iwaniuk et al. 2018). Proportions 
of these four species changed depending on year and study as well as region of sampling. Other species were also detected were not present in all published results, for example $F$. langsethiae (Lukanowski \& Sadowski 2008), F. sporotrichioides (Kuzdraliński

et al. 2017), F. tricinctum (Wiśniewska et al. 2014).

Weather in 2009 was more favorable for FHB development than in 2010, which is also reflected in the difference in amount of Fusarium DNA and mycotoxins (Table 5).

Air temperature $\left({ }^{\circ} \mathrm{C}\right)$ and sum of rainfall $(\mathrm{mm})$ in May, June and July of 2009 and 2010 in Radzików and in 2010 in 25 locations

Temperatura powietrza $\left({ }^{\circ} \mathrm{C}\right)$ i suma opadów (mm) w maju, czerwcu i lipcu 2009 i 2010 w Radzikowie i w 2010 w 25 miejscowościach

\begin{tabular}{|c|c|c|c|c|}
\hline \multirow{2}{*}{$\begin{array}{l}\text { Month } \\
\text { Miesiąc }\end{array}$} & \multicolumn{2}{|c|}{25 miejscowości (średnia; zakres) } & \multicolumn{2}{|c|}{ Radzików } \\
\hline & Rainfall & Temperature & Rainfall & Temperature \\
\hline & Suma opadów & Temperatura & Suma opadów & Temperatura \\
\hline \multicolumn{5}{|c|}{2009} \\
\hline May maj & & & 71.8 & 13.7 \\
\hline June czerwiec & & & 84.0 & 16.3 \\
\hline July lipiec & & & 138.6 & 20.0 \\
\hline \multicolumn{5}{|c|}{2010} \\
\hline May maj & $134.1(74.5-227.8)$ & $12.3(8.7-14.7)$ & 149.6 & 13.7 \\
\hline June czerwiec & $59.0(13.1-166.6)$ & $16.8(14.1-17.9)$ & 64.6 & 17.8 \\
\hline July lipiec & $110.4(31.6-238.2)$ & $20.9(20.0-21.8)$ & 131.6 & 21.7 \\
\hline
\end{tabular}

In some regions (e.g., Radzików) in 2010, the drought conditions occurred in June and July with high temperatures and infrequent, heavy rainfalls. Despite differences in weather and limited number of samples in 2009, F. graminearum was occurring more frequently than $F$. culmorum. Amount of DNA of the first species was also higher in both years. While $F$. culmorum DNA was very low in 2010, we can conclude that dry weather is affecting to a large extent occurrence of this species (Scherm et al. 2013). In the Netherlands in 2009 incidence and amount of F. culmorum DNA was similarly low as in our study (van der Fels-Klerx et al. 2012). Authors found this species only in $2 \%$ of samples and DNA concentration was 80 -times lower than for $F$. graminearum.

Tomczak et al. (2002) analyzed Fusarium species causing FHB epidemics in 1998 and 1999 in two regions of Poland. In 1998 in northern and central regions $F$. avenaceum dominated, being followed by Fusarium graminearum and F. culmorum with similar frequency. In 1999 , ranking of species was the same; however, frequency of $F$. graminearum was 3-5 times higher than
F. culmorum. Authors reminds that no $F$. graminearum was detected in the previous decade (1980's) in wheat grown in Northern Poland. Kuzdraliński et al. (2018) found dominance of $F$. graminear$u m$ in samples of wheat grain from South-Eastern Poland collected in 2013. F. culmorum was fifth species as regards frequency. Wiśniewska et al. (2014) found that F. culmorum was the most common species on strong infected heads of wheat in 2009. They analyzed samples from six locations, and only in two from Southern Poland F. graminearum prevailed over F. culmorum. Iwaniuk et al. (2018) observed variability in $F$. culmorum and $F$. graminearum frequency in grain of spring wheat collected in 2017 in North-Eastern Poland. First species dominated in two cultivars and the second in two others. Stępień and Chełkowski (2010) summarized frequencies of Fusarium species infecting wheat heads in Poland from 1985 to 2009. In 1985 F. avenaceum and Microdochium nivale dominated, F. culmorum being the third species. In 2009, $F$. graminearum dominated and $F$. culmorum was the second species with about half frequency of first species. Increase in $F$. graminearum was obvious; 
however, differences between years were substantial. F. culmorum predominated in some localities in several studies. It may be explained by the influence of local weather conditions on the frequency of species. Variability of Fusarium species can be high even at the single field level (Xu et al. 2008b)

Sexual stage of Fusarium graminearum is Gibberella zeae, which produces sexual spores (ascospores) in perithecia (Desjardins 2003). For $F$. culmorum perfect stage is not known and fungus produces only asexual spores - macroconidia (Scherm et al. 2013). Thus F. graminearum can disperse and infect host plants with ascospores and macroconidia, whereas $F$. culmorum only with macroconidia. Nature of $F$. graminearum is the homothallic which allows the production of large masses of ascospores and effectively compete against F. culmorum (Waalwijk et al. 2003). In a German study, the important contribution of ascospores to inoculum pressure was emphasized (Obst et al. 2002). Ascospores required a relative humidity below 53\%, whereas macroconidia required relative humidity of above $80 \%$ for germination, as was observed by Beyer et al. (Beyer et al. $2005)$. It can be another factor favoring $F$. graminearum over $F$. culmorum under dry conditions.

Fusarium poae was the most frequently species detected in grain (100\% of samples in 2009 and $74 \%$ of samples in 2010). In 2010 in 9 samples out of 50 it was the only Fusarium species present. However, amount of $F$. poae DNA was about 10-times lower than $F$. graminearum DNA in dry 2010 year and up to 200 times lower in year 2009 of weather favorable for FHB. According to other reports $F$. poae was frequently isolated from wheat spikes and kernels in Poland (Goliński et al. 1996; Lenc et al. 2015; Kuzdraliński et al. 2017; Iwaniuk et al. 2018). This is a weak pathogen of cereals, however, is widespread on wheat in Europe (Vogelgsang et al. 2008, 2019; Isebaert et al. 2009; Xu et al. 2003; Lindblad et al. 2013; Polišenská et al. 2021). Vogelgsang et al. (2019) in eight-year survey found similar pattern. The highest frequency of $F$. graminearum and $F$. poae in winter wheat, but 3-times higher amount of $F$. graminearum. Audenaert et al. (2009) observed dominance of $F$. poae in Flanders in 2007 and in 2008 it was isolated with lower frequency. In 2007 , the infection pressure was very high as compared with 2008. The authors suggested that this is because $F$. poae was a secondary pathogen infecting the weakened heads. Additionally, high frequency of occurrence of $F$. poae was explained by its sporulation strategy. This species produces very large amounts of microconidia in a dry powdery form that can easily invade cereal heads. It could be true for dry conditions and wind dispersal, because for splash dispersal Hörberg (2002) did not find any difference in patterns between $F$. poae microconidia and much larger macroconidia of F. culmorum. It is to add that $F$. poae as a weak pathogen was rarely isolated when only FHB symptomatic wheat kernels were analyzed (Bilska et al. 2018).

$\mathrm{Xu}$ et al. (2008a) associated $F$. poae with dry and warm weather conditions, whereas $F$. graminearum with warm/humid conditions. $F$. avenace$u m$ and $F$. culmorum were both associated with niches of cooler/wet/humid conditions. This was confirmed for $F$. poae by Covarelli et al. (2013) but they observed that in dry season of 2009 $F$. graminearum was replaced by $F$. poae and also by $F$. avenaceum. Parikka et al. (2012) who expected increase of importance of $F$. poae (accompanied by F. langsethiae) in more dry conditions of Scandinavia stated the similar. Similarly, the results obtained by Chrpova et al. (2016) showed increase in F. poae occurrence in 2012 in Czech Republic. The weather in 2012 was warmer and drier than in the other studied years $(2011,2013)$. The weather conditions in the most regions of Poland in 2010 were dry and warm during and after flowering. Results showed that this favored $F$. poae spread on wheat. Only in the South/South-Eastern Poland weather was warm and humid, and $F$. graminearum dominated in the grain samples from this region.

Low $F$. poae DNA in the grain observed in our study could be explained by lower aggressiveness of this species as compared to F. graminearum (Vogelgsang et al. 2008; Stenglein 2009). It was also found that $F$. poae that predominated in wheat glumes was not detected in grain, which was infected by F. culmorum, F. avenaceum and $M$. nivale (Doohan et al. 1998). Authors did not detect $F$. graminearum in wheat samples (collected in England, UK in 1994) which is good example of later Fusarium species shift in Europe. Polley and Turner (Polley and Turner 1995) found that $F$. poae was associated with distinct glume spot lesions and was the most frequently isolated from glumes. Doohan (1998) supposed that the infection process and colonization by $F$. poae differs from that of other Fusarium species causing FHB.

Fusarium poae is known as NIV producer (Thrane et al. 2004; Schollenberger et al. 2006). Consequently, we detected NIV in most samples but at very low quantities. In Poland, NIV was found primarily in oats infected by $F$. poae (Perkowski et al. 1997). Edwards et al. (Edwards et al. 2012) found that correlation of nivalenol concentration 
in oat grain and $F$. poae DNA was highly significant but only accounted for $9 \%$ of the variance. It showed that other species such as $F$. graminearum and $F$. culmorum were involved in NIV production. NIV chemotypes of these species are not frequent in Poland. Stępień et al. (2008) found that only 12\% of $F$. graminearum isolates in Poland displayed the NIV chemotype.

Besides NIV, F. poae isolates were found to produce wide range of toxins including type $\mathrm{A}$ and $\mathrm{B}$ trichothecenes, beauvericin, enniatins, moniliformin, and others (Bottalico and Perrone 2002; Thrane et al. 2004; Uhlig et al. 2006; Stenglein 2009; Somma et al. 2010). The surveys of wheat harvested in Poland in 2006 and 2007 as well as in 2013 showed that increased importance of $F$. poae in the FHB complex in Poland (Kulik and Jestoi 2009; Wolny-Koładka et al. 2015).

In 1994 Norwegian researchers found "powdery $F$. poae" strains which were the most abundant potential producer of HT-2 and T-2 toxins in cereals (Kosiak et al. 2003). In 1999 these F. poae strains were proved to produce T-2 toxin (Torp and Langseth 1999). Strains originated mainly from Norwegian oats but were found also on wheat in Austria and the Netherlands. Further these strains were described as a new species $F$. langsethiae by Torp and Nierenberg (2004). The species was being found primarily in Northern Europe on oats and barley (Yli-Mattila et al. 2008; Edwards et al. 2012).

Occurrence of $F$. langsethiae on wheat in Poland was confirmed in 2008 (Lukanowski et al. 2008). This species was found mainly in Northern Poland (including Radostowo mentioned in present study), however it was present in some samples of wheat grain from Central Poland (Lukanowski and Sadowski 2008). In 2009 F. langsethiae was found on wheat grain in the Netherlands but at low level ( $8 \%$ of samples) (van der Fels-Klerx et al. 2012). Presence of $F$. langsethiae was detected by Czaban et al. (2015) in years 2008 - 2010 in South-Eastern Poland. Percentages of winter wheat kernels colonized by this species was low. It ranged from 0 to $2.9 \%$ in susceptible cultivar 'Kris' in 2010. In our research, we did not detect $F$. langsethiae in 2009, however limited number of samples was analyzed. In 2010, DNA of this species was found mainly in samples from Northern Poland and in only one from southern region at low concentration.

$F$. langsethiae and $F$. poae are favored by dry conditions (Supronienè et al. 2010; Parikka et al. 2012; Czaban et al. 2015), however it seems that the first species prefer lower temperatures than the former. Kokkonen et al. (2012) found that $F$. langsethiae produced the highest amount of the type A trichothecenes at $15^{\circ} \mathrm{C}$, whereas $F$. poae could produce beauvericin at both cool and warm conditions.

Deoxynivalenol (DON) was the toxin which amount was the highest in the analysed grain samples. In their review, Perkowski et al. (2004) summarized results of several papers on mycotoxins in cereal grain in Poland. Amounts of DON detected in wheat grain were similar to these in present work in 2010, but lower than in 2009. DON concentration in 2009 and 2010 was similar to that detected by Czaban et al. (2015) in four winter wheat cultivars in the same years. Authors found DON mainly in the grain from 2009 and in 2010, DON was present only in small concentrations. In 2017 (moist season) and 2018 (dry season), Bryła et al. (2019) observed similar pattern of DON concentration: low in 2018 and high in 2017. Lindblad et al. (2013) found similar amounts of DON in grain of winter wheat collected in Sweden in 2009 and 2011. We detected higher amounts of DON, especially in 2009. In 2010, it was also higher, however did not exceeded the legislative limit of $1250 \mu \mathrm{g} / \mathrm{kg}$ like in Swedish samples in 2011.

DON accumulation was closely associated with the presence of $F$. graminearum (Bryła et al. 2015; Lindblad et al. 2013). Coefficient was very high in 2009, because of high DON accumulation and high $F$. graminearum DNA amount in grain. In this year DON concentration correlated strongly also with $F$. culmorum DNA despite its low concentration in the most of samples. In 2010, coefficients were lower and significant only for $F$. graminearum.

Nivalenol (NIV) accumulation was much lower than DON and amounts was comparable to detected by Bryła et al. (2015) in 2017 and 2018. Its concentration was significantly associated with the presence of $F$. graminearum and $F$. poae in 2009. In 2010, coefficients were insignificant but positive for all three possible NIV producers: $F$. culmorum, $F$. graminearum and $F$. poae. Xu et al. (2003) studied wheat grain samples harvested in 2001 from UK, Ireland, Italy, and Hungary. They did not find quantitative relationships between amount of Fusarium DNA and the concentration of the mycotoxins in the grain. However, for total $F$. graminearum and F. culmorum DNA and DON concentration linear model was nearly significant. In the next survey (Xu et al. 2008a) they studied Fusarium species frequency and mycotoxin content in wheat samples from the same countries over two years (2003-2004). They found DON being 
the most frequently detected toxin. DON amount correlated strongly with $F$. graminearum DNA. NIV was related significantly only to the amount of $F$. culmorum DNA. As regards ZEN, authors found strong association with both $F$. culmorum and $F$. graminearum. In 2005 in Poland, the highest amount of ZEN was found in wheat grain infected by F. graminearum (Gromadzka et al. 2008). In grain were $F$. culmorum was the main pathogen, ZEN content was 10-times lower. We found higher amounts of ZEN in both 2009 and 2010 comparing with results obtained by Czaban et al. (2015) for the same years (all values below LOD $=10$ $\mu \mathrm{g} / \mathrm{kg}$ ). However, ZEN content was very diverse and high in individual samples (above $100 \mu \mathrm{g} / \mathrm{kg}$ ).

\section{Conclusions}

1. The most common species detected in wheat grain in 2009 was $F$. graminearum and $F$. poae in 2010.The highest DNA content in wheat grain in both years was found for F. graminearum.

2. F. graminearum DNA was detected in $100 \%$ of the grain samples in 2009 and in 50\% of the samples in 2010.

3. In 2010 F. culmorum DNA was detected only in $25 \%$ of the grain samples and content of DNA of this species was low.

4. DNA of $F$. langsethiae was detected in 2010 mainly in the grain samples originating from Northern Poland.

5. Deoxynivalenol (DON) was detected in the most grain samples.

6. DON amount in the grain was higher in 2009 than in 2010.

7. DON accumulation in the grain was significantly correlated with the presence of $F$. graminearum DNA.

\section{References}

Audenaert, K., van Broeck, R., van Bekaert, B., de Witte, F., Heremans, B., Messens, K., Höfte, M., \& Haesaert, G. (2009). Fusarium head blight (FHB) in Flanders: population diversity, inter-species associations and DON contamination in commercial winter wheat varieties. European Journal of Plant Pathology, 125 (3), 445-458.

Beyer, M., Verreet, J.-A., \& Ragab, W. S. M. (2005). Effect of relative humidity on germination of ascospores and macroconidia of Gibberella zeae and deoxynivalenol production. International Journal of Food Microbiology, 98 (3), 233-240.

Bilska, K., Jurczak, S., Kulik, T., Ropelewska, E., Olszewski, J., Żelechowski, M., \& Zapotoczny, P. (2018). Species composition and trichothecene genotype profiling of Fusarium field isolates recovered from wheat in Poland. Toxins, 10 (8), 325.

Birr, T., Hasler, M., Verreet, J.-A. \& Klink, H. (2020) Composition and predominance of Fusarium species causing Fusarium head blight in winter wheat grain depending on cultivar susceptibility and meteorological factors. Microorganisms, 8, 617.

Birzele, B., Meier, A., Hindorf, H., Krämer, J., \& Dehne, H. W. (2002). Epidemiology of Fusarium infection and deoxynivalenol content in winter wheat in the Rhineland, Germany. European Journal of Plant Pathology, 108, 667-673.

Bottalico, A., \& Perrone, G. (2002). Toxigenic Fusarium species and mycotoxins associated with head blight in small-grain cereals in Europe. European Journal of Plant Pathology, 108, 611-624.

Bryła, M., Ksieniewicz-Woźniak, E., Yoshinari, T., Waśkiewicz, A., \& Szymczyk, K. (2019). Contamination of wheat cultivated in various regions of Poland during 2017 and 2018 agricultural seasons with selected trichothecenes and their modified forms. Toxins, 11 (2), 88.

Chandelier, A., Nimal, C., André, F., Planchon, V., \& Oger, R. (2011). Fusarium species and DON contamination associated with head blight in winter wheat over a 7-year period (2003-2009) in Belgium. European Journal of Plant Pathology, 130 (3), 403-414.

Chełkowski, J., Gromadzka, K., Stępień, Ł., Lenc, L., Kostecki, M., \& Berthiller, F. (2012). Fusarium species, zearalenone and deoxynivalenol content in preharvest scabby wheat heads from Poland. World Mycotoxin Journal, 5 (2), 133-141.

Chrpová, J., Šíp, V., Sumíková, T., Salava, J., Palicová, J., Štočková, L., Džuman, Z., \& Hajšlová, J. (2016). Occurrence of Fusarium species and mycotoxins in wheat grain collected in the Czech Republic. World Mycotoxin Journal, 9 (2), 317-327.

Covarelli, L., Beccari, G., Prodi, A., Generotti, S., Etruschi, F., Juan, C., Ferrer, E., \& Mañes, J. (2015). Fusarium species, chemotype characterisation and trichothecene contamination of durum and soft wheat in an area of central Italy. Journal of the Science of Food and Agriculture, 95 (3), 540-551.

Czaban, J., Wróblewska, B., Sułek, A., Mikos, M., Boguszewska, E., Podolska, G., \& Nieróbca, A. (2015). Colonisation of winter wheat grain by Fusarium spp. and mycotoxin content as dependent on a wheat variety, crop rotation, a crop management system and weather conditions. Food Additives \& Contaminants. Part A, Chemistry, Analysis, Control, Exposure \& Risk Assessment, 32 (March), 799-807.

Desjardins, A. E. (2003). Gibberella from $A$ (venaceae) to Z (eae). Annual Review of Phytopathology, 41, 177-198. 
Dinolfo, M. I., \& Stenglein, S. A. (2014). Fusarium poae and mycotoxins: Potential risk for consumers. Boletin de La Sociedad Argentina de Botanica, 49 (1), 5-20.

Doohan, F. M., Parry, D. W., Jenkinson, P., \& Nicholson, P. (1998). The use of species-specific PCR-based assays to analyse Fusarium ear blight of wheat. Plant Pathology, 47 (2), 197-205.

Edwards, S. G., Imathiu, S. M., Ray, R. V., Back, M., \& Hare, M. C. (2012). Molecular studies to identify the Fusarium species responsible for HT-2 and T-2 mycotoxins in UK oats. International Journal of Food Microbiology, 156 (2), 168-175.

Gagkaeva, T., Gavrilova, O., Orina, A., Lebedin, Y., Shanin, I., Petukhov, P., \& Eremin, S. (2019). Analysis of toxigenic Fusarium species associated with wheat grain from three regions of Russia: Volga, Ural, and West Siberia. Toxins, $11(5)$.

Giraud, F., Pasquali, M., El Jarroudi, M., Vrancken, C., Brochot, C., Cocco, E., Hoffmann, L., Delfosse, P., \& Bohn, T. (2010). Fusarium head blight and associated mycotoxin occurrence on winter wheat in Luxembourg in 2007/2008. Food Additives \& Contaminants. Part A, Chemistry, Analysis, Control, Exposure \& Risk Assessment, 27 (6), 825-835.

Goliński, P., Perkowski, J., Kostecki, M., GrabarkiewiczSzczęsna, J., \& Chełkowski, J. (1996). Fusarium species and Fusarium toxins in wheat in Poland - a comparison with neighbour countries. Sydowia, 48 (1), 12-22.

Gromadzka, K., Chełkowski, J., Stępień, Ł., \& Goliński, P. (2008). Occurrence of zearalenone in wheat and maize grain in Poland. Cereal Research Communications, 36 (Supplement 6), 361-363.

Hofgaard, I. S., Aamot, H. U., Torp, T., Jestoi, M., Lattanzio, V. M. T., Klemsdal, S. S., Waalwijk, C., van der Lee, T., \& Brodal, G. (2016). Associations between Fusarium species and mycotoxins in oats and spring wheat from farmers' fields in Norway over a six-year period. World Mycotoxin Journal, 9 (3), 365-378.

Hörberg, H. M. (2002). Patterns of splash dispersed conidia of Fusarium poae and Fusarium culmorum. European Journal of Plant Pathology, 108, 73-80.

Horevaj, P., Milus, E. A., \& Bluhm, B. H. (2011). A real-time qPCR assay to quantify Fusarium graminearum biomass in wheat kernels. Journal of Applied Microbiology, 111 (2), 396-406.

Imathiu, S. M., Edwards, S. G., Ray, R. V., \& Back, M. A. (2013). Fusarium langsethiae - a HT-2 and T-2 toxins producer that needs more attention. Journal of Phytopathology, 161 (1), 1-10.

Isebaert, S., De Saeger, S., Devreese, R., Verhoeven, R., Maene, P., Heremans, B., \& Haesaert, G. (2009). Mycotoxin-producing Fusarium species occurring in winter wheat in Belgium (Flanders) during 2002-2005. Journal of Phytopathology, 157 (2), 108-116.
Iwaniuk, P., Konecki, R., Snarska, K., \& Łozowicka, B. (2018). Quantitative evaluation of Fusarium species and crop quality traits in wheat varieties of northeastern Poland. Journal of Plant Protection Research, 58 (4), 413-419.

Jestoi, M. N., Paavanen-Huhtala, S., Parikka, P., \& Yli-Mattila, T. (2008). In vitro and in vivo mycotoxin production of Fusarium species isolated from Finnish grains. Archives Of Phytopathology And Plant Protection, 41 (8), 545-558.

Kokkonen, M., Jestoi, M., \& Laitila, A. (2012). Mycotoxin production of Fusarium langsethiae and Fusarium sporotrichioides on cereal-based substrates. Mycotoxin Research, 28 (1), 25-35.

Kosiak, B., Torp, M., Skjerve, E., \& Thrane, U. (2003). The prevalence and distribution of Fusarium species in Norwegian cereals: a survey. Acta Agriculturae Scandinavica, Section B - Soil \& Plant Science, 53 (4), 168-176.

Kulik, T., \& Jestoi, M. (2009). Quantification of Fusarium poae DNA and associated mycotoxins in asymptomatically contaminated wheat. International Journal of Food Microbiology, 130 (3), 233-237.

Kuzdraliński, A., Nowak, M., Szczerba, H., Dudziak, K., Muszyńska, M., \& Leśniowska-Nowak, J. (2017). The composition of Fusarium species in wheat husks and grains in south-eastern Poland. Journal of Integrative Agriculture, 16 (7), 1530-1536.

Laszlo, E., Varga, B., \& Veisz, O. (2011). Composition of Fusarium species causing natural spike infection in wheat. Acta Agronomica Hungarica, 59 (3), 255-260.

Lenc, L., Czecholiński, G., Wyczling, D., Turów, T., \& Kaźmierczak, A. (2015). Fusarium head blight (FHB) and Fusarium spp. on grain of spring wheat cultivars grown in Poland. Journal of Plant Protection Research, 55 (3), 266-277.

Lindblad, M., Gidlund, A., Sulyok, M., Börjesson, T., Krska, R., Olsen, M., \& Fredlund, E. (2013). Deoxynivalenol and other selected Fusarium toxins in Swedish wheat Occurrence and correlation to specific Fusarium species. International Journal of Food Microbiology, 167 (2), 284-291.

Lukanowski, A., Lenc, L., \& Sadowski, C. (2008). First Report on the occurrence of Fusarium langsethiae isolated from wheat kernels in Poland. Plant Disease, 92 (3), 488-488.

Lukanowski, A., \& Sadowski, C. (2008). Fusarium langsethiae on kernels of winter wheat in Poland Occurrence and mycotoxigenic abilities. Cereal Research Communications, 36, 453-457. https://doi.org/10.1556/ CRC.36.2008.Suppl.B.40

Maiorano, A., Blandino, M., Reyneri, A., \& Vanara, F. (2008). Effects of maize residues on the Fusarium spp. infection and deoxynivalenol (DON) contamination of wheat grain. Crop Protection, 27 (2), 182-188.

Miller, J. D. (2008). Mycotoxins in small grains and maize: 
old problems, new challenges. Food Additives \& Contaminants. Part A, Chemistry, Analysis, Control, Exposure \& Risk Assessment, 25 (2), 219-230.

Nicolaisen, M., Suproniene, S., Nielsen, L. K., Lazzaro, I., Spliid, N. H., \& Justesen, A. F. (2009). Real-time PCR for quantification of eleven individual Fusarium species in cereals. Journal of Microbiological Methods, 76 (3), 234-240.

Nielsen, L. K., Jensen, J. D., Nielsen, G. C., Jensen, J. E., Spliid, N. H., Thomsen, I. K., Justesen, A. F., Collinge, D. B., \& Jørgensen, L. N. (2011). Fusarium head blight of cereals in Denmark: species complex and related mycotoxins. Phytopathology, 101 (8), 960-969.

Nielsen, L. K., Justesen, A. F., Jensen, J. D., \& Jørgensen, L. N. (2013). Microdochium nivale and Microdochium majus in seed samples of Danish small grain cereals. Crop Protection, 43, 192-200.

Niessen, L. (2007). PCR-based diagnosis and quantification of mycotoxin producing fungi. International Journal of Food Microbiology, 119, 38-46.

Obst, A., Gunther, B., Beck, R., Lepschy-von Gleissenthall, J., \& Tischner, H. (2002). Weather conditions conducive to Gibberella zeae and Fusarium graminearum head blight of wheat. Journal of Applied Genetics, 43A, 185-192.

Obst, A., Lepschy-von Gleissenthall, J., \& Beck, R. (1997). On the etiology of Fusarium head blight of wheat in south Germany - preceding crops, weather conditions for inoculum production and head infection, proneness of the crop to infection and mycotoxin production. Cereal Research Communications, 25 (3), 699-703.

Parikka, P., Hakala, K., \& Tiilikkala, K. (2012). Expected shifts in Fusarium species' composition on cereal grain in Northern Europe due to climatic change. Food Additives \& Contaminants. Part A, Chemistry, Analysis, Control, Exposure \& Risk Assessment, 29 (10), 1543-1555.

Parry, D. W., Jenkinson, P., \& McLeod, L. (1995). Fusarium ear blight (scab) in small grain cereals - a review. Plant Pathology, 44 (2), 207-238.

Perkowski J., Chełkowski J., Goliński P. (2004) Occurrence of mycotoxins in cereals, plants, foods and feeds in Poland. In: Logrieco A., Visconti A. (eds) An Overview on Toxigenic Fungi and Mycotoxins in Europe. Springer, Dordrecht.

Perkowski, J., Plattner, R. D., Golinski, P., Vesonder, R. F., \& Chelkowski, J. (1990). Natural occurrence of deoxynivalenol, 3-acetyl-deoxynivalenol, 15-acetyl-deoxynivalenol, nivalenol, 4,7-dideoxynivalenol, and zearalenone in Polish wheat. Mycotoxin Research, 6, 7-12.

Perkowski, J., Stachowiak, J., Kiecana, I., Golinski, P., \& Chelkowski, J. (1997). Natural occurrence of Fusarium mycotoxins in Polish cereals. Cereal Research Communications, 25 (3), 379-380.

Polišenská, I., Jirsa, O., Salava, J., Sedláčková, I., \& Frydrych,
J. (2021). Fusarium mycotoxin content and Fusarium species presence in Czech organic and conventional wheat. World Mycotoxin Journal, 14 (2), 201-211.

Polley, R. W., \& Turner, J. A. (1995). Surveys of stem base diseases and fusarium ear diseases in winter wheat in England, Wales and Scotland, 1989-1990. Annals of Applied Biology, 126 (1), 45-59.

Scherm, B., Balmas, V., Spanu, F., Pani, G., Delogu, G., Pasquali, M., \& Migheli, Q. (2013). Fusarium culmorum: causal agent of foot and root rot and head blight on wheat. Molecular Plant Pathology, 14 (4), 323-341.

Schollenberger, M., Müller, H. M., Rüfle, M., Suchy, S., Plank, S., \& Drochner, W. (2006). Natural occurrence of 16 Fusarium toxins in grains and feedstuffs of plant origin from Germany. Mycopathologia, 161 (1), 43-52.

Somma, S., Alvarez, C., Ricci, V., Ferracane, L., Ritieni, A., Logrieco, A., \& Moretti, A. (2010). Trichothecene and beauvericin mycotoxin production and genetic variability in Fusarium poae isolated from wheat kernels from northern Italy. Food Additives and Contaminants Part A Chemistry, Analysis, Control, Exposure and Risk Assessment, 27 (5), 729-737.

Stenglein, S. A. (2009). Fusarium poae: A pathogen that needs more attention. Journal of Plant Pathology, 91 (1), 25-36.

Stępień, Ł., \& Chełkowski, J. (2010). Fusarium head blight of wheat: pathogenic species and their mycotoxins. World Mycotoxin Journal, 3 (2), 107-119.

Stępień, Ł., Popiel, D., Koczyk, G., \& Chełkowski, J. (2008). Wheat-infecting Fusarium species in Poland - Their chemotypes and frequencies revealed by PCR assay. Journal of Applied Genetics, 49 (4), 433-441.

Sundheim, L., Brodal, G., Hofgaard, I. S., \& Rafoss, T. (2013). Temporal variation of mycotoxin producing fungi in Norwegian cereals. Microorganisms, 1 (1), 188-198.

Supronienė, S., Justesen, A. F., Nicolaisen, M., Mankevičienė, A., Dabkevicius, Z., Semaskiene, R., \& Leistrumaite, A. (2010). Distribution of trichothecene and zearalenone producing Fusarium species in grain of different cereal species and cultivars grown under organic farming conditions in Lithuania. Annals of Agricultural and Environmental Medicine, 17 (1), 79-86.

Supronienè, S., Sakalauskas, S., Mankevičienè, A., Barčauskaitė, K., \& Jonavičienė, A. (2016). Distribution of B type trichothecene producing Fusarium species in wheat grain and relation to mycotoxins DON and NIV concentrations. Zemdirbyste-Agriculture, 103 (3), 281-288.

Talas, F., Parzies, H. K., \& Miedaner, T. (2011). Diversity in genetic structure and chemotype composition of Fusarium graminearum sensu stricto populations causing wheat head blight in individual fields in Germany. European Journal of Plant Pathology, 131 (1), 39-48.

Thrane, U., Adler, A., Clasen, P.-E., Galvano, F., Langseth, W., Lew, H., Logrieco, A., Nielsen, K. F., \& Ritieni, A. 
(2004). Diversity in metabolite production by Fusarium langsethiae, Fusarium poae, and Fusarium sporotrichioides. International Journal of Food Microbiology, 95 (3), 257-266.

Tomczak, M., Wiśniewska, H., Stẹpień, Ł., Kostecki, M., Chełkowski, J., \& Goliński, P. (2002). Deoxynivalenol, nivalenol and moniliformin in wheat samples with head blight (scab) symptoms in Poland (1998-2000). European Journal of Plant Pathology, 108 (7), 625-630.

Torp, M., \& Langseth, W. (1999). Production of T-2 toxin by a Fusarium resembling Fusarium poae. Mycopathologia, 147 (2), 89-96.

Torp, M., \& Nirenberg, H. I. (2004). Fusarium langsethiae sp. nov. on cereals in Europe. International Journal of Food Microbiology, 95, 247-256.

Uhlig, S., Jestoi, M., \& Parikka, P. (2007). Fusarium avenaceum - the North European situation. International Journal of Food Microbiology, 119 (1-2), 17-24.

Uhlig, S., Torp, M., \& Heier, B. T. (2006). Beauvericin and enniatins $\mathrm{A}, \mathrm{A} 1, \mathrm{~B}$ and $\mathrm{B} 1$ in Norwegian grain: A survey. Food Chemistry, 94 (2), 193-201.

Vaughan, M., Backhouse, D., \& Del Ponte, E. M. (2016). Climate change impacts on the ecology of Fusarium graminearum species complex and susceptibility of wheat to Fusarium head blight: A review. World Mycotoxin Journal, 9 (5), 685-700.

van der Fels-Klerx, H. J., de Rijk, T. C., Booij, C. J. H., Goedhart, P. W., Boers, E. A. M., Zhao, C., Waalwijk, C., Mol, H. G. J., \& van der Lee, T. A. J. (2012). Occurrence of Fusarium head blight species and Fusarium mycotoxins in winter wheat in the Netherlands in 2009. Food Additives and Contaminants - Part A Chemistry, Analysis, Control, Exposure and Risk Assessment, 29 (11), 17161726.

Vogelgsang, S., Beyer, M., Pasquali, M., Jenny, E., Musa, T., Bucheli, T. D., Wettstein, F. E., \& Forrer, H. R. (2019). An eight-year survey of wheat shows distinctive effects of cropping factors on different Fusarium species and associated mycotoxins. European Journal of Agronomy, 105, 62-77.

Vogelgsang, S., Sulyok, M., Hecker, A., Jenny, E., Krska, R., Schuhmacher, R., \& Forrer, H. R. (2008). Toxigenicity and pathogenicity of Fusarium poae and Fusarium avenaceum on wheat. European Journal of Plant Pathology, 122 (2), 265-276.

Waalwijk, C., Kastelein, P., De Vries, I., Kerényi, Z., Van Der Lee, T., Hesselink, T., Köhl, J., \& Kema, G. (2003). Major changes in Fusarium spp. in wheat in the Netherlands. European Journal of Plant Pathology, 109 (7), 743-754.

Waalwijk, C., van der Heide, R., de Vries, I., van der Lee, T., Schoen, C., Costrel-de Corainville, G., HäuserHahn, I., Kastelein, P., Köhl, J., Lonnet, P., Demarquet, T., \& Kema, G. H. J. (2004). Quantitative detection of Fusarium species in wheat using TaqMan. European
Journal of Plant Pathology, 110 (5-6), 481-494.

Wiśniewska, H., Stępień, Ł., Waśkiewicz, A., Beszterda, M., Góral, T., \& Belter, J. (2014). Toxigenic Fusarium species infecting wheat heads in Poland. Central European Journal of Biology, 9 (2), 163-172.

Wolny-Koladka, K., Lenart-Boroń, A., \& Boroń, P. (2015). Species composition and molecular assessment of the toxigenic potential in the population of Fusarium spp. isolated from ears of winter wheat in southern Poland. Journal of Applied Botany and Food Quality, 144, 139-144.

Xu, X.-M., Nicholson, P., Thomsett, M. A., Simpson, D., Cooke, B. M., Doohan, F. M., Brennan, J., Monaghan, S., Moretti, A., Mule, G., Hornok, L., Beki, E., Tatnell, J., Ritieni, A., \& Edwards, S. G. (2008). Relationship between the fungal complex causing Fusarium head blight of wheat and environmental conditions. Phytopathology, 98 (1), 69-78.

Xu, X. M., Parry, D. W., Nicholson, P., Thomsett, M. A., Simpson, D., Edwards, S. G., Cooke, B. M., Doohan, F. M., Brennan, J. M., Moretti, a., Tocco, G., Mule, G., Hornok, L., Giczey, G., \& Tatnell, J. (2005). Predominance and association of pathogenic fungi causing Fusarium ear blightin wheat in four European countries. European Journal of Plant Pathology, 112 (2), 143-154.

Xu, X. M., Parry, D. W., Nicholson, P., Thomsett, M. A., Simpson, D., Edwards, S. G., Cooke, B. M., Doohan, F. M., Monaghan, S., Moretti, A., Tocco, G., Mule, G., Hornok, L., Béki, E., Tatnell, J., \& Ritieni, A. (2008). Within-field variability of Fusarium head blight pathogens and their associated mycotoxins. European Journal of Plant Pathology, 120 (1), 21-34.

Xu, X., \& Nicholson, P. (2009). Community ecology of fungal pathogens causing wheat head blight. Annual Review of Phytopathology, 47 (1), 83-103.

Xu, X., Parry, D. W., Nicholson, P., Thomsett, M. A., Simpson, D., Edwards, S. G., Cooke, B. M., Doohan, F. M., Van Maanen, A., Moretti, A., Tocco, G., Mule, G., Hornok, L., Giczey, G., Tatnell, J., \& Ritieni, A. (2003). Is the amount of mycotoxins in cereal grains related to the quantity of Fusarium DNA? Aspects of Applied Biology, 68, 101-108.

Xue, A. G., Chen, Y., Seifert, K., Guo, W., Blackwell, B. A., Harris, L. J., \& Overy, D. P. (2019). Prevalence of Fusarium species causing head blight of spring wheat, barley and oat in Ontario during 2001-2017. Canadian Journal of Plant Pathology, 41 (3), 392-402.

Yli-Mattila, T., Paavanen-Huhtala, S., Jestoi, M., Parikka, P., Hietaniemi, V., Gagkaeva, T., Sarlin, T., Haikara, A., Laaksonen, S., \& Rizzo, A. (2008). Real-time PCR detection and quantification of Fusarium poae, F. graminearum, F. sporotrichioides and F. langsethiae in cereal grains in Finland and Russia. Archives of Phytopathology and Plant Protection, 41 (4), 243-260. 